\title{
REVISÃO DO GÊNERO DINOCORIS BURMEISTER, 1835 (HETEROPTERA, PENTATOMIDAE, DISCOCEPHALINAE)
}

MIRIAM BECKER JOCÉLIA GRAZIA

\section{ABSTRACT}

Dinocoris Burmeister 1835 is revised on the basis of a morphological study emphasizing genitalia and the geographical distribution of the species. Fifteen species - five new - are recognized, and are here grouped in two subgenera. Subgenus Dinocoris Burmeister, 1835 includes D. (D) variolosus (Linnaeus, 1758); D. (D.) histrio (Linnaeus, 1758); D. (D.) maculatus (Laporte, 1832); D. (D) corrosus (Herrich-Schaeffer, 1844); D. (D.) antennatus (Dallas, 1851); D. (D.) gibbus (Dallas, 1852); D. (D.) ramosus (Walker, 1868); D. (D.) gibbosus (Fallou, 1889) D. (D.) rufitarsus Ruckes, 1958; D. (D.) reticulatus, sp. n.; D. (D.) fabricii, sp. n.; and D. (D.) nigroantennatus, sp. n. Subgenus Praedinocoris, subg. n. includes D. (P.) lineatus (Dallas, 1852); D. (P.) prolineatus, sp. n.; and D. (P.) nigrodecoratus, sp. n. Bryelica Walker, 1868 is considered a junior synonym of Dinocoris. An illustration of the dorsal facies is given for D. (D.) reticulatus, $s p$. n., D. (P.) prolineatus, $s p$. n. and for D. (P.) nigrodecoratus, $s p . n$. The male and female genitalia are illustrated for all species. A key is given to saparate suggenera and species.

\section{HISTÓRIA TAXONÔMICA}

1758

Linnaeus descreveu Cimex histrio, C. peregrinator e C. variolosus (veja Stal, 1868 e 1872).

1803

Fabricius descreveu Halys variolosa (veja Hahn, 1834).

1832

Laporte descreveu uma espécie do Brasil, e a atribuiu ao gênero Dinidor Latreille, 1829, denominando-a Dinidor maculatus; desmembrou Dinidor em dois subgêneros: o subgênero tipo para $D$. maculatus e o subgênero Eusthenes para Tessaratoma robusta Lepeletier \& Serville, da India.

\section{4}

Hahn propôs o gênero Empicoris para a espécie que acreditou ser Halys variolosa Fabricius, 1803 (veja Stal, 1868 e 1872). (O nome Empicoris fora usado por Wolff, 1811 para um gênero de Reduviidae - veja Agassiz, 1846 e McAtee \& Malloch, 1923).

\section{5}

Burmeister propôs um novo nome para Dinidor, em função do que considerou um erro etimológico, ou seja, o nome que deveria ter sido dado para o caráter morfológico apontado seria Dinodes e este estava pré-ocupado; propôs, então, o nome Dinocoris, ampliou a descrição do gênero e o subdividiu em dois grupos: a divisão "A" para Dinidor maculatus Laporte, com quatro artículos antenais, da Bahia e Pará, e a divisão "B" para Pentatoma macraspis Perty, 1834, com cinco artículos antenais, da Bahia, que hoje corresponde à Antiteuchus (Neodine) macraspis (Perty), espécie tipo do subgênero Neodine Kirkaldy, 1909. 
1837

Spinola redescreveu Empicoris Hahn com duas subdivisões: na primeira incluiu E. variolosus Hahn (pl. 47 fig. 146) = Halys variolosa Fabricius; na segunda divisão incluiu Empicoris marmoreus como nova espécie descrita do Brasil (veja Herrich-Schaeffer, 1844: 43).

1843

Amyot \& Serville reestabeleceram o nome Dinidor para o gênero pois consideraram que o erro etimológico apontado por Burmeister (1835) não justificaria a troca de um nome já consagrado pela ciência; ampliaram a descrição de Dinidor maculatus Laporte com base em macho e fêmea procedentes do Brasil.

1844

Herrich-Schaeffer ampliou a descrição do gênero Empicoris, adotando este nome por ter precedência sobre Dinocoris Burmeister, 1835 e aceitou as divisões propostas por Spinola (1837): na primeira divisão incluiu E. maculatus que então ilustrou. Com E. marmoreus, da segunda divisão, ele sinonimizou $D$. annulatus Herrich-Schaeffer, 1836, figurada nesse trabalho sob o nome de $D$. macraspis e incluiu uma nova espécie do Paraguai que denominou $E$. renggerii; redescreveu $E$. maculatus Laporte e comparou com E. variolosus. (O conceito da segunda divisão de Spinola hoje corresponde a Antiteuchus Dallas, 1851). Ainda nesse trabalho, Herrich-Schaeffer descreveu E. corrous, do Paraguai, que aproximou de E. maculatus sem, entretanto, situá-la nas divisões propostas por Spinola, mencionando que se distingue pela forma da cabeça.

1846

Agassiz propôs o nome Empidocoris em substituição a Empicoris Hahn, por estar pré-ocupado por Empicoris Wolff, 1811.

1848

Erichson descreveu Empicoris cariosus e citou E. maculatus para a "British Guiana" (Guiana).

1851

Dallas, seguindo a nomenclatura de Amyot \& Serville, descreveu Dinidor antennatus, da América do Sul e Pará. Ainda, mencionou mais duas espécies: D. corrosus (Herrich-Schaeffer, 1844), da Colômbia, e D. variolosus (Linnaeus, 1758), cometendo o equívoco de considerar Halys valiolosa Fabricius, 1803 e Dinidor maculatus Laporte, 1832 como sinônimos de D. variolosus (Linnaeus).

1852

Dallas descreveu Dinidor lineatus, do Pará; no mesmo trabalho descreveu Dinidor gibbus, do Brasil, com base em uma fêmea onde restavam apenas os três últimos segmentos antenais.

1867

Stal incluiu Dinocoris em sua chave para os gêneros de "Discocephalidum", e o distinguiu dos demais por possuir antenas de quatro artículos, o primeiro superando em muito o ápice da cabeça, pela cabeça pequena, não foliácea, e pelo escutelo algo elevado na base. Este procedimento, na verdade, reflete o conceito da divisão "A" de Burmeister (1835).

1868

Stal considerou Dinocoris Burmeister, 1835 e Empicoris Hahn, 1834 como gêneros distintos. Considerou Dinidor maculatus Laporte, 1832 sinônimo de Halys variolosa Fabricius, 1803, o que criou um problema de homonímia com Cimex variolosus Linnaeus, 1758. Por este motivo, adotou Dinocoris maculatus (Laporte, 1832). Indicou, também, que o material tratado por Dallas em 1851 como Dinidor variolosus Linnaeus $(=$ variolosus Fabricius $\mathrm{e}=$ maculatus 
Laporte), tratava-se, na verdade, de Dinocoris maculatus Laporte. Em Empicoris, incluiu E. variolosus (Linnaeus, 1758) considerando sinônimos: $E$. cariosus Erichson, 1848 e ainda E. peregrinatorem (Linnaeus, 1758) e E. variolosus Hahn, 1834. Destacou que o exemplar de que trata Hahn, em 1834, como sendo Halys variolosa Fabricius, 1803, representava, provavelmente uma espécie distinta daquela de Fabricius.

\section{7}

Walker também seguiu a nomenclatura de Amyot \& Serville (1843) e aceitou o conceito de Dallas (1851), listando no gênero Dinidor as espécies D. variolosus, D. antennatus, D. corrosus e D. cariosus.

\section{8}

Walker descreveu Dinidor strigatus, da região amazônica, e a aproximou de D. antennatus Dallas, 1851, ignorando a espécie Dinidor lineatus descrita por Dallas em 1852. Ainda, em 1868, Walker descreveu o gênero Bryelica para uma espécie de "Oajaca", México, que denominou B. ramosa, ressaltando que os exemplares examinados tinham as antenas mutiladas, tendo apenas os três primeiros artículos. Aproximou seu gênero de Antiteuchus Dallas distinguindo-o deste pela estrutura da cabeça e da membrana das asas anteriores.

\section{2}

Stal admitiu como gêneros Dinocoris e Empicoris, utilizando, a nível genérico, os caracteres apontados por Burmeister (1835) para separar as duas espécies D. maculatus e D. macraspis. Em Dinocoris, Stal admitiu dois subgêneros: Dinocoris, com duas espécies (macraspis e variegatus) e Mecistorhinus Dallas, 1851 com dois grupos de espécies, ficando o grupo Mecistorhinus Dallas, 1851 com dois grupos de espécies, o grupo Mecistorhinus com oito espécies e o grupo Antiteuchus com duas espécies. No gênero Empicoris reconheceu dois grupos de espécies: no grupo "a" - Empicoris - incluiu lineatus Dallas, variolosus Linnaeus, antennatus Dallas, peregrinator Linnaeus, maculatus Laporte e corrosus Herrich-Schaeffer; no grupo "aa" - Bryelica - incluiu apenas ramosus Walker. Listou, ainda, gibbus Dallas sem, entretanto, situá-la em nenhum grupo. Esclareceu, também, que a espécie considerada por Hahn (1834) como sendo Halys variolosa Fabricius tratava-se, efetivamente, de Cimex variolosus Linnaeus. Finalmente, colocou histrio Linnaeus na sinonímia de peregrinator Linnaeus e strigatus Walker na sinonímia de lineatus Dallas. (O que Stal chamou, em 1867, de Mecistorhinus e em 1872 de Dinocoris corresponde, hoje, a Antiteuchus.)

1880

Distant seguiu Stal (1872) na conceituação dos gêneros Empicoris e Dinocoris.

1889

Fallou descreveu Brochymena gibbosa, de Minas Gerais, comparando-a com B. quadripustulata (Fabricius, 1775).

1891

Bergroth descreveu Empicoris hiulcus, de Minas Gerais, comparando-a com E. lineatus.

1892

Bergroth transferiu B. gibbosa para o gênero Empicoris.

1893

Lethierry \& Severin relacionaram para o gênero Empicoris as espécies citadas por Stal (1872), acrescentando E. hiulcus.

Kirkaldy fez uma revisão detalhada da nomenclatura e designou Dinidor maculatus Laporte como tipo de Dinocoris Burmeister - Halys variolosa Fabri- 
cius é o tipo do gênero Empicoris Hahn, por monotipia. Kirkaldy fez as seguintes alterações e adições, em relação ao trabalho de Stal (1872): corrigiu a data de publicação das espécies de Linnaeus - Cimex histrio, C. peregrinator e C. variolosus - para 1758; reconheceu a prioridade de histrio, descrita na página 442, sobre peregrinator, descrita na página 444; revalidou strigatus Walker, retirando-a da sinonímia de lineatus Dallas; revalidou o gênero Bryelica.

1923

McAtee \& Malloch apontaram que Empicoris Hahn, 1834 se encontrava ocupado por Empicoris Wolff, 1811 e, com base em Kirkaldy (1909) propuseram a sua substituição por Dinocoris Burmeister por ser o próximo nome disponível, sem mencionar a proposta feita por Agassiz (1846).

1940

Costa Lima chamou também atenção para a homonímia de Empicoris. Ruckes (1958a) descreveu Dinocoris robustus, do Peru, com base em fêmeas, sugerindo a possibilidade de que se tratasse de uma "raça geográfica" de $D$. maculatus. Ainda no mesmo ano, Ruckes (1958b) descreveu D. rufitarsus, do Panamá, comparando-a com $D$. variolosus (Linnaeus); nesse trabalho descreveu também $D$. binotata, do Brasil, considerando-a muito próxima a $D$. rufitarsus.

1962

Piran colocou $D$. binotata Ruckes na sinonímia de D. corrosus.

\section{MATERIAL E MÉTODOS}

As coleções entomológicas, às quais pertencem os exemplares examinados neste trabalho, estão indicadas pelas seguintes siglas:

AMNH - American Museum of Natural History, New York, EUA.

$\mathrm{BM}(\mathrm{NH})$ - British Museum (Natural History), Londres, Inglaterra.

CAS - California Academy of Sciences, San Francisco, EUA.

CIS - California Insect Survey, College of Agriculture, University of California, Berkeley, EUA.

DZPR - Departamento de Zoologia, Universidade Federal do Paraná, Curitiba, Brasil.

DZRS - Departamento de Zoologia, Universidade Federal do Rio Grande do Sul, Porto Alegre, Brasil.

FACE - Faculdade de Agronomia, Universidade Federal do Ceará, Fortaleza, Brasil.

INPA - Instituto Nacional de Pesquisas da Amazônia, Manaus, Brasil.

IOC - Fundação Instituto Oswaldo Cruz, Rio de Janeiro, Brasil.

IZA - Instituto de Zoologia Agrícola, Universidad Central de Venezuela, Maracay, Venezuela.

LS - Coleção La Salle, Caracas, Venezuela.

MA - Museu Anchieta, Porto Alegre, Brasil.

MG - Museu Paraense Emílio Goeldi, Belém, Brasil.

MLP - Facultad de Ciencias Naturales y Museo, La Plata, Argentina.

MN - Museu Nacional, Rio de Janeiro, Brasil.

MP - Muséum National d'Histoire Naturelle, Paris, França.

MZSP - Museu de Zoologia, Universidade de São Paulo, Brasil.

NMNH - National Museum of Natural History, Washington D.C., EUA.

SEM - Snow Entomological Museum, University of Kansas, Lawrence, EUA.

ZM - Zoologiske Museum, Copenhague, Dinamarca.

ZUEC - Departamento de Zoologia, Universidade Estadual de Campinas,

Sáo Paulo, Brasil. 
Foram examinados os exemplares tipo das seguintes espécies: Halys variolosa Fabricius, 1803, Dinocoris binotata Ruckes, 1958, Dinidor antennatus Dallas, 1851, Bryelica ramosa Walker, 1868, Dinocoris robustus Ruckes, 1958, Dinocoris rufitarsus Ruckes, 1958 e Dinidor strigatus Walker, 1868.

No tratamento da genitália foi utilizado $\mathrm{KOH}$ a $10 \%$, a frio, para maceração e, para diafanização, foi utilizado fenol P.A.; a coloração foi feita em Vermelho Congo. Foi adotada a nomenclatura proposta por Dupuis (1970) na terminologia das peças da genitália.

As medidas estão expressas em milímetros e correspondem à medida e amplitude obtida de cinco machos e cinco fêmeas, sempre que disponíveis, e referem-se às seguintes especificações: comprimento da cabeça, do pronoto, do escutelo e comprimento total do corpo incluindo a membrana, ao longo da linha média longitudinal do corpo; comprimento dos artículos antenais em vista dorsal; largura da cabeça ao nível dos olhos; largura do pronoto ao nível dos úmeros; largura do escutelo junto aos ângulos basais; largura abdo:ninal ao nivel do $3 .^{\circ}$ segmento.

\section{Gênero Dinocoris Burmeister, 1835}

Cimex Linnaeus, 1758: 441, partim.

Halys Fabricius, 1803: 180, partim.

Dinidor Laporte, 1832: 64, nec Latreille, 1829; Amyot \& Serville, 1843: 110; Dallas, 1851: 165-166.

Empicoris Hahn, 1834: 55, nec Wolff, 1811; Spinola, 1837: 282, partim; Herrich-Schaeffer, 1844: 43; Stal, 1872: 10; Distant, 1880: 48; Lethierry

\& Severin, 1893: 88; Kirkaldy, 1909: 220.

Dinocoris Burmeister, 1835: 363 e 400, partim; Stal, 1867: 501; McAtee \& Malloch, 1923: 162.

Empidocoris Agassiz, 1846: 137, emend. pro Empicoris Hahn, 1834.

Bryelica Walker, 1868: 547; Stal, 1872: 11; Kirkaldi, 1909: 221.

Espécie tipo: Halys variolosa Fabricius, 1803 = Dinidor maculatus Laporte, 1832; designado por Kirkaldy, 1909.

Forma geral do corpo de semielíptica a largamente ovalada, mais ou menos achatada ou dorsalmente convexa. Antenas e patas dotadas de longos e densos pêlos; superfície do corpo também pilosa porém com menos densidade. Espécies com tamanho médio a grande.

Cabeça mais ou menos triangular, com comprimento pouco menor que o pronoto. Olhos subglobulares, mais ou menos proeminentes. Antenas com 4 ou 5 artículos; primeiro artículo antenal mais espesso que os demais, ultrapassando as jugas em pelo menos um terço de seu comportamento. Búculas percurrentes e pouco elevadas, ultrapassando em pouco uma linha imaginária que passa pela margem posterior dos olhos.

Pronoto trapezoidal; margem anterior apenas pouco maior que a largura da cabeça, projetada de cada lado em um pequeno dente triangular, às vezes ausente. Largura do pronoto ao nível dos úmeros menor do que a largura do abdome. Mesosterno elevado, de cada lado do sulco mediano em calos lisos; metasterno hexagonal, carenado. Escutelo triangular, alcançando ou ultrapassando o meio do sexto segmento abdominal. Freno extendendo-se além do meio do escutelo. Cório ultrapassando o escutelo; sutura da membrana, ao nível do exocório, projetada em triângulo sobre a membrana, continuando-se quase reta ao nível do endocório.

Ângulos póstero-laterais do conexivo em ângulo reto. Sulco mediano, na superfície ventral do abdome, largo e raso, estendendo-se até o quinto segmento.

Tíbias plano-sulcadas na face dorsal.

Genitália do macho: Pigóforo com um par de notórias projeções no bordo dorsal, de posição lateral; margem ventral elevada em projeções à exceção de $D$. (D.) gibbus; X segmento perpendicular ao plano sagital do 
pigóforo. Phallus: phallotheca tubular em linhas gerais; conjuntiva ausente; vésica simples, sem processo (subgênero Praedinocoris) ou com um processo único, em sua base, sempre projetado para a face dorsal (subgênero Dinocoris); aparelho articular simples, sem particularidade em qualquer das espécies do gênero; placas basais em lâmina simples, disposta paralelamente ao plano frontal da phallotheca, a qual repousa sobre o ponticulus transversalis; conetivos dorsais em fita; processi capitati não desenvolvidos.

Genitália da fêmea: Bordo posterior do segmento VII desde muito rasamente sinuado até cônvaco na área que recobre a base dos gonocoxitos $\mathrm{B}$; margem posterior dos laterotergitos 8 no conjunto formando uma linha leve mente convexa. Bordos suturais dos gonocoxitos 8 não retilíneos, algo sinuados, muitas vezes deixando ver entre eles o espessamento que existe ao longo da linha mediana longitudinal do triangulum (gonapófises 8); bordos posteriores e externos sem angulações, em arco suave. Laterotergitos 9 de contorno convexo na parte não encoberta pelos gonocoxitos 8 , ápice atingindo ou pouco ultrapassando a banda transversal, dorsal ao $\mathrm{X}$ segmento, que liga os laterotergitos 8. Gonocoxitos 9 e gonapófises 9 formando uma peça única, transversal, na margem anterior (distal) na qual se situa o espessamento da íntima vaginal, simples, desde em forma de bolha até de dedal. Chitinellipsen presentes, ou não, de cada lado do espessamento da íntima vaginal. Este padrão se aplica a todas as espécies do gênero, não havendo caracteres distintivos entre os dois subgêneros.

Considerações sobre a morfologia da genitália:

Para os machos, tanto o pigóforo quanto o ductus seminis e Aussenwand apresentam elementos que servem para a caracterização das espécies e, no subgênero Dinocoris, permitem reunir as espécies em três grupos. O exame do pigóforo, a seco, deslocado ligeiramente do sétimo segmento abdominal, é suficiente para a identificação a nível de espécie. O exame do phallus, como elemento adicional para a identificação das espécies exige, entretanto, preparação (maceração, diafanização e coloração), sendo que o aparelho articular, por sua simplicidade, não apresenta elementos úteis. No subgênero Praedinocoris a posição correta para observação dos parâmeros é colocando o pigóforo em vista posterior.

A genitália da fêmea serve como elemento subsidiário para a identificação das espécies. No material a seco, as diferenças encontradas nas placas genitais não são marcantes; deve-se levar em conta o contorno da margem posterior do VII segmento e o formato dos gonocoxitos 8 , em especial o contorno dos bordos suturais e margem posterior. Os laterotergitos 8 e laterotergitos 9, muito simples, não oferecem elementos diagnósticos nítidos. As vias genitais ectodérmicas, após preparação, contêm elementos importantes para identificação a nível de espécie. Interessam os seguintes aspectos: diâmetro e comprimento relativo dos diferentes setores do ductus receptaculi; formato e tamanho da capsula seminalis e comprimento e diâmetro da pars intermedialis. A presença ou ausência de dentes na capsula seminalis deve ser vista com reservas, pois o número e o formato dos dentes pode variar dentro de uma mesma espécie. Os gonocoxitos 9 e gonapófises 9 não oferecem elementos de valia para a identificação e estão ilustrados apenas para uma única espécie (D. (D.) lineatus, fig. 70). Da mesma forma, as placas genitais diafanizadas não contribuem de maneira significativa para a identificação das espécies pois a dissecção e preparação distorcem o formato e posição relativa das peças; encontram-se ilustradas apenas para uma espécie (D. (D.) lineatus, fig. 69).

No subgênero Dinocoris, as espécies estudadas podem ser arranjadas em três grupos, em função da forma e tamanho das expansões laterais do bordo dorsal do pigóforo e da parede ventral do pigóforo, bem como do nível atingido pelo ápice dos parâmeros em relação àquelas expansões. Grupo $\mathrm{A}$ : $D$. variolosus, $D$. maculatus, $D$. antennatus e $D$. reticulatus. Expansões laterais do bordo dorsal do pigóforo pequenas, menores que o comprimento do pigóforo sobre a linha mediana, entre a abertura basal e o bordo dorsal. Parede ventral do pigóforo levemente sinuada no meio; projeções laterais perfeita- 
mente visíveis em vista dorsal. Parâmeros ultrapassando em muito o ápice das expansões dorsais do pigóforo. Grupo B: D. corrosus, D. ramosus, $D$. gibbosus, D. rufitarsus e D. fabricii. Expansões laterais do bordo dorsal do pigóforo alongadas, tão longas quanto o comprimento do pigóforo sobre a linha mediana, entre a abertura basal e o bordo dorsal. Parede ventral do pigóforo côncava em consequiência das nítidas expansões de seus lados. Parâmeros atingido ou pouco ultrapassando as expansões dorsais do pigóforo. Grupo C: D. gibbus. Bordo dorsal do pigóforo, de cada lado do X segmento, projetado em curta e larga expansão, como num punho fechado, não expandido sobre o X segmento, fendido no meio; parede ventral do pigóforo não elevada, desprovida de expansões; parâmeros perfeitamente visíveis em vista ventral.

\section{Chave para as espécies do gênero Dinocoris}

1. Comprimento da cabeça diante dos olhos maior do que a distância interocular; jugas estendendo-se além do clípeo em cerca de um quinto de seu comprimento; metasterno em forma de hexágono de lados iguais, de tal maneira que a distância entre as mesocoxas é igual à distância de uma mesocoxa à metacoxa correspondente; segundo artículo antenal totalmente negro (Praedinocoris) .........

- Comprimento da cabeça diante dos olhos igual ou menor do que a distância interocular; jugas estendendo-se além do clípeo em um sexto a um oitavo de seu comprimento, ou igualando-o; metasterno hexagonal com as margens anterior e posterior maiores que as demais de tal forma que as mesocoxas estão mais distanciadas entre si do que das metacoxas correspondentes; segundo artículo antenal nunca totalmente negro (Dinocoris)

2. Jugas afilando-se em direção ao épice e aí formando uma incisura em "V"; terceiro e quarto artículos antenais com anéis amarelados na base; pronoto com quatro faixas longitudinais ferrugíneas ......

- Jugas subparalelas, arredondadas no ápice e sobrepostas sobre o clípeo; antenas, com exceção do primeiro artículo, totalmente negras; pronoto com duas faixas longitudinais ferrugíneas, além de manchas junto à margem anterior e sobre os úmeros .... D. (P.) nigrodecoratus

3. Membrana dos hemiélitros reticulada; linhas longitudinais ferrugíneas do pronoto ligadas por linhas transversais que marginam as cicatrizes.

D. (P.) prolineatus

- Membrana dos hemiélitros com veias longitudinais não formando retículos; linhas longitudinais ferrugíneas do pronoto não ligadas por linhas transversais $\ldots \ldots \ldots \ldots \ldots \ldots \ldots \ldots \ldots \ldots \ldots \ldots \ldots \ldots \ldots \ldots$. (P.) lineatus

4. Antenas com quatro artículos .................... 5

- Antenas com cinco artículos (às vezes o segundo e o terceiro fusio-

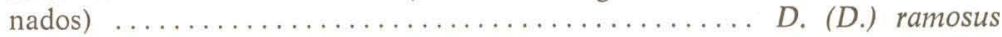

5. Margens ântero-laterais do pronoto formando uma projeção triangular ao nível dos ângulos umerais, ou estes desenvolvidos em espinhos

- Ápice das margens ântero-laterais em ângulo reto, não formando pro-

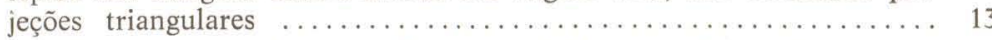

6. Ângulos umerais desenvolvidos em nítido espinho voltado para

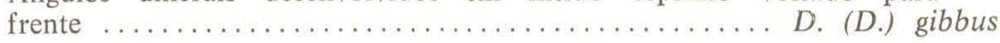

- Ângulos umerais com projeção triangular formada pelo ápice das

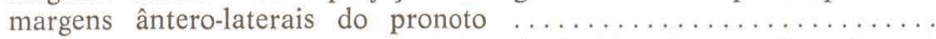

7. Abdome totalmente ocre-amarelado, destituído de manchas ferrugíneas, espiráculos concolores; puncturações ferrugíneas do pronoto e pontuações ferrugíneas do cório não formando faixas $D$. (D.) variolosus

- Abdome com manchas ferrugíneas; espiráculos negro-ferrugíneos . . 8

8. Cório de coloração testácea, com uma mancha ferrugínea no ápice d. veia radial D. (D.) maculatus 
- Cório de coloração ocre-amarelada ou testácea, dotado de pontuações ferrugíneas irregularmente distribuídas ou formando faixas trans-

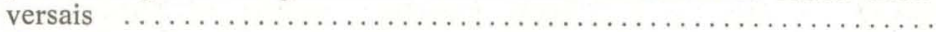

9. Faixas ferrugíneas transversais presentes no cório, às vezes estenden-

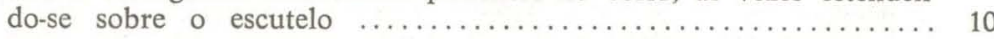

- Faixas ferrugíneas transversais ausentes no cório ............ 11

10. Antenas quase totalmente negras; faixas ferrugíneas transversais apenas no cório $\ldots \ldots \ldots \ldots \ldots \ldots \ldots \ldots \ldots \ldots \ldots \ldots \ldots \ldots \ldots \ldots \ldots \ldots$. (D.) nigroantennatus

- Antenas predominantemente ocre-alaranjadas com anéis negros no extremo apical do segundo artículo, negras na metade ou mais do terceiro e nos dois terços apicais do quarto; faixas ferrugíneas transversais do cório estendendo-se sobre o escutelo .... D. (D.) antennatus

11. Pronoto com um par de nítidas e amplas faixas ferrugíneas longitudinais que se continuam pela calosidade basal do escutelo .......

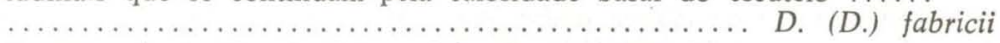

- Pronoto destituído de faixas ferrugíneas longitudinais ou, se presentes, são inconspícuas, sempre mais estreitas que o diâmetro de um olho e não continuadas sobre a calosidade basal do escutelo ..

12. Tarsos geralmente ocre-amarelados; último artículo tarsal com coloração negra que ocupa, pelo menos, mais da metade posterior ......

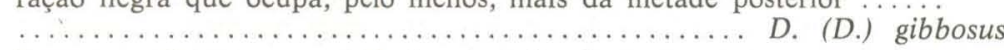

- Tarsos totalmente avermelhados (ocasionalmente presente uma mancha escurecida no ápice dorsal do terceiro artículo) D. (D.) rufitarsus

13. Pronoto nitidamente puncturado; cório com uma faixa transversal de pontuações ferrugíneas que se estende sobre o escutelo; áreas ocre-amareladas do cório e escutelo destituídas de pontuações

\section{D. (D.) histrio}

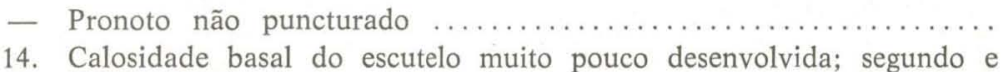
terceiro artículos antenais fusionados; pontuações negro-ferrugíneas do pronoto formando oito linhas longitudinais e uma linha transversal que parte dos ângulos umerais e ocupa pouco mais dos terços laterais; escutelo e cório com linhas ferrugíneas delimitando manchas subcalosas ocre-amareladas determinando um padrão reticulado na coloração da superfície dorsal ................. D. (D.) reticulatus

- Calosidade basal do escutelo bem desenvolvida; pontuações ferrugíneas do pronoto, escutelo e cório muito densa e irregularmente distribuída, formando numerosos e rasos sulcos que conferem à superfície dorsal um aspecto corroído ou corrugado; uma faixa calosa, irregular, ocre-amarelada ou avermelhada disposta junto à margem posterior das cicatrizes do pronoto; calos basais do escutelo ocreamarelados ou avermelhados ................... (D.) corrosus

\section{Subgênero Dinocoris Burmeister, 1835}

Forma geral do corpo oval, alargada, convexo na superfície dorsal e plano na superfície ventral. Face dorsal com pontuações grosseiras e/ou puncturações de coloração ferrugínea ou negra, distribuídas de maneira peculiar, em especial no pronoto e base do escutelo, entre as puncturações algumas áreas subcalosas, lisas e brilhantes; demais pontuações ferrugíneas, quando presentes, menores e distribuídas de distintas maneiras no cório, dois terços apicais do escutelo e conexivo, nas diferentes espécies.

Cabeça: Jugas nitidamente sinuadas adiante dos olhos, convergentes e progressivamente estreitando-se em direção ao ápice, aí separadas entre si, justapostas ou sobrepostas por sobre o clípeo. Jugas igualando o clípeo $(D$. ramosus) ou muito pouco ultrapassando-o (de um sexto a um oitavo de seu comprimento). Comprimento da cabeça adiante dos olhos igual ou menor do que a distância interocular. Antenas com quatro ou cinco artículos; nas espé- 
cies de cinco artículos o segundo e terceiro são geralmente subfusionados e o terceiro artículo é o maior; nas demais, o segundo artículo é o maior. Rostro estendendo-se pelo quarto urosternito, alcançando o terço anterior (D. maculatus), a metade (D. antennatus) ou o terço posterior (D. gibbosus) deste segmento.

Pronoto: Margem anterior um pouco elevada atrás da cabeça, seguida de um sulco transversal junto à margem anterior das cicatrizes, estas mais ou menos túmidas; margens ântero-laterais moderadamente sinuadas e refletidas, junto ao ápice posterior, às vezes formando uma projeção triangular adjacente aos ângulos umerais. Em D. gibbus, os ângulos umerais se desenvolvem em espinhos. Margens póstero-laterais e margem posterior moderadamente sinuadas. Mesosterno com uma estreita carena longitudinal em continuação à do metasterno, às vezes inconspícua nos dois terços anteriores. Metasterno hexagonal com as margens anterior e posterior retas, maiores que as demais, de tal forma que as mesocoxas estão mais distanciadas entre si do que da metacoxa correspondente. Área evaporatória da metapleura ocupando os dois terços internos da largura do segmento. Peritrema ostiolar variável, evanescente em $D$. histrio e nas demais espécies até em lâmina elevada que ocupa mais da metade da margem anterior da área evaporatória metapleural.

Escutelo: base do escutelo com uma calosidade nítida ou apenas com o semi-círculo e a linha média longitudinal mais elevados; nítidos calos, lisos $\mathrm{P}$ amarelados, do tamanho de um olho, adjacentes aos ângulos basais do escute1o. Ápice do escutelo variảvel, às vezes emarginado de cada lado. Hemiélitros: cório atingindo ou pouco ultrapassando os ângulos ântero-internos do sétimo segmento do conexivo, nunca alcançando o ângulo póstero-lateral deste segmento, especialmente nos machos. Membrana pouco ultrapassando o ápice do abdome; veias em geral mais escuras, irregularmente ramificadas, às vezes sub-ramosas. Conexivo amplamente exposto.

Genitália do macho: Cápsula genital do pigóforo, em vista dorsal, de aspecto variado em função do formato e extensão das expansões laterais de seu bordo dorsal e do grau com que este avança por sobre o X segmento. Expansões dorso-laterais, na base, incompleta ou completamente marcadas por falsa linha de sutura. Parede dorsal do pigóforo, no meio, íntegra ou percorrida parcial ou totalmente por linha de "sutura". X segmento em tubo fortemente convexo. Parede ventral do pigóforo (exceto em $D$. gibbus) elevada, margem larga, côncava ou sinuada, de cada lado expandida em projeções obtusas ou pontiagudas, entre estas e as projeções do bordo dorsal resultando um hiato ao longo do plano frontal do pigóforo (ausente em $\mathrm{D}$. maculatus). Parâmetros em braços alongados, geralmente algo recurvos para os lados, formato diferindo em cada espécie e determinado pela extensão e posição relativa de carenas (exceto em $D$. gibbus e $D$. fabricii).

Genitália da fêmea: Conforme descrito para o gênero.

Espécie tipo: Halys variolosa Fabricius, $1803=$ Dinidor maculatus Laporte, 1832 .

Dinocoris (Dinocoris) variolosus (Linnaeus, 1758)

(Figs. 4, 17, 30, 40, 56, 71, 84)

Climex variolosus Linnaeus, 1758: 445; 1767: 721; De Geer, 1773: 328-329, est. 34, fig. 1 .

Empicoris variolosus; Hahn, 1834: 56, fig. 146; Herrich-Schaeffer, 1844: 44-45; Stal, 1868: 20; 1872: 11; Lethierry \& Severin, 1893: 89; Kirkaldy, 1909: 220.

Dinidor antennatus Dallas, 1851: 166, partim (macho e fêmea "S. America"). Dinidor variolosus; Walker, 1867: 199.

Localidade tipo: “America". Rolander, citado por Linnaeus, coletou em Suriname e nas Antilhas (Papavero, 1971). in litt.).

Tipo: depositado na "Linnaean Society of London Collection" (Ruckes, 


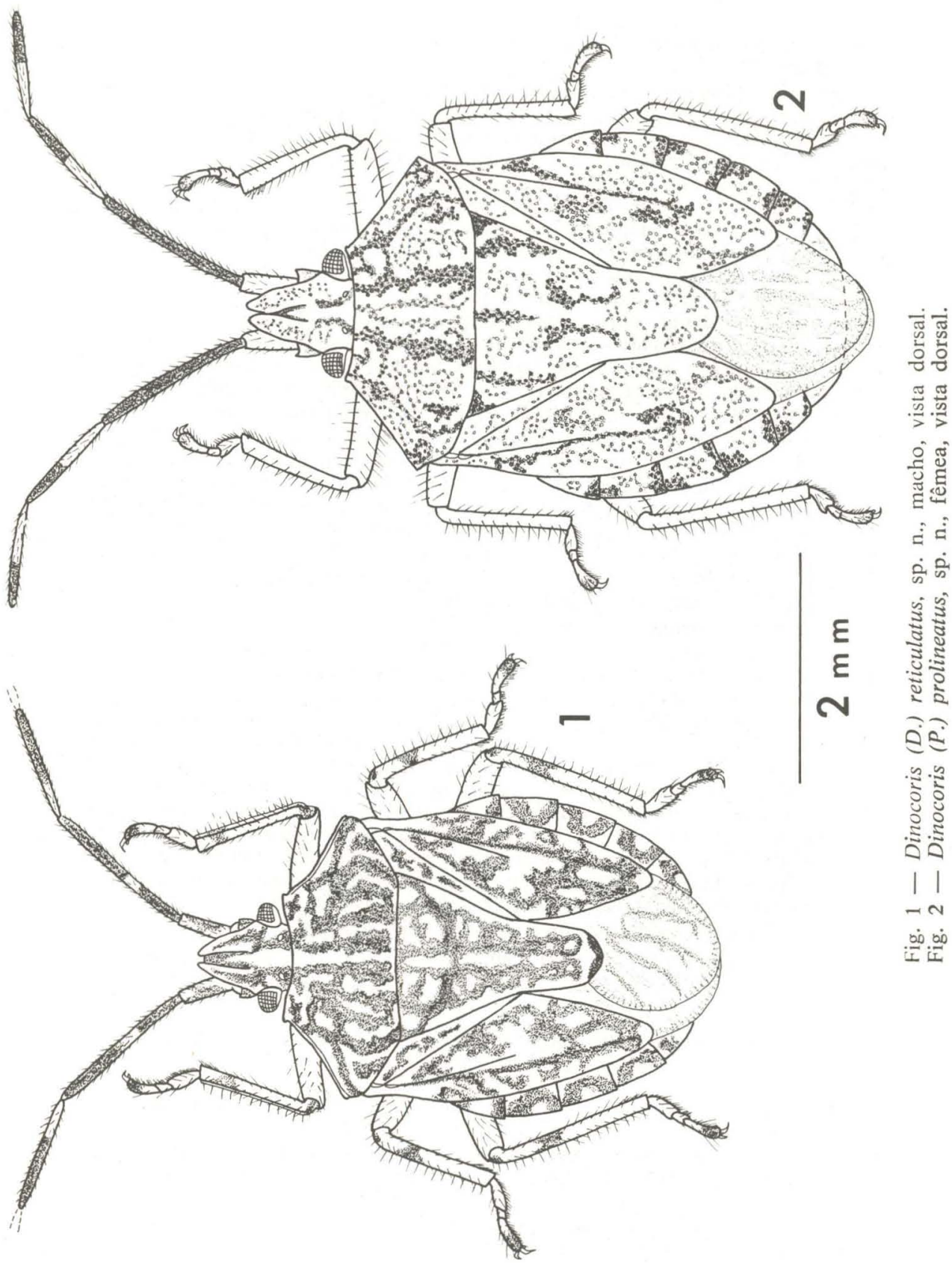




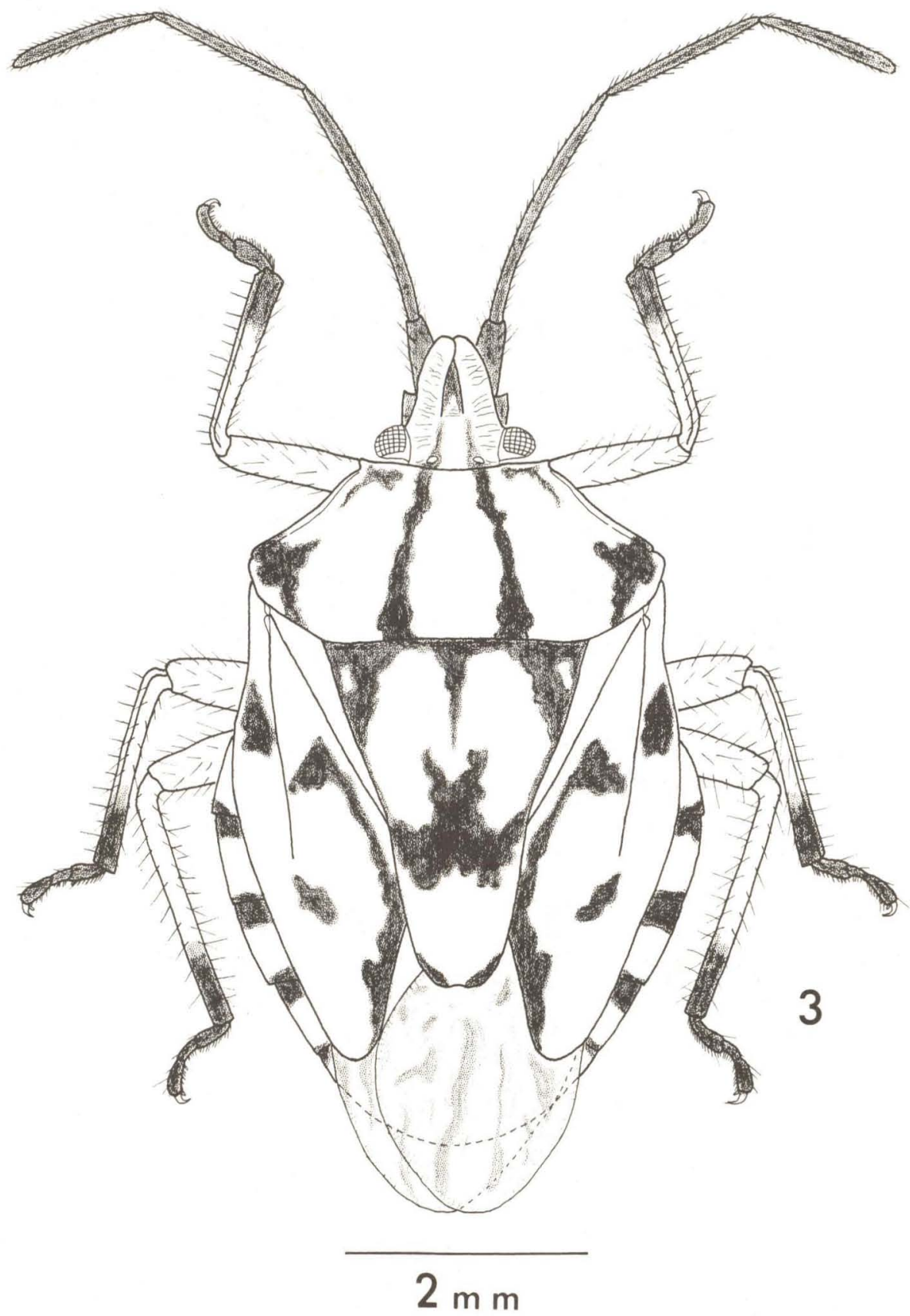

Fig. $3^{\prime}$ - Dinocoris (P.) nigrodecoratus sp. n., fêmea, vista corsal. 

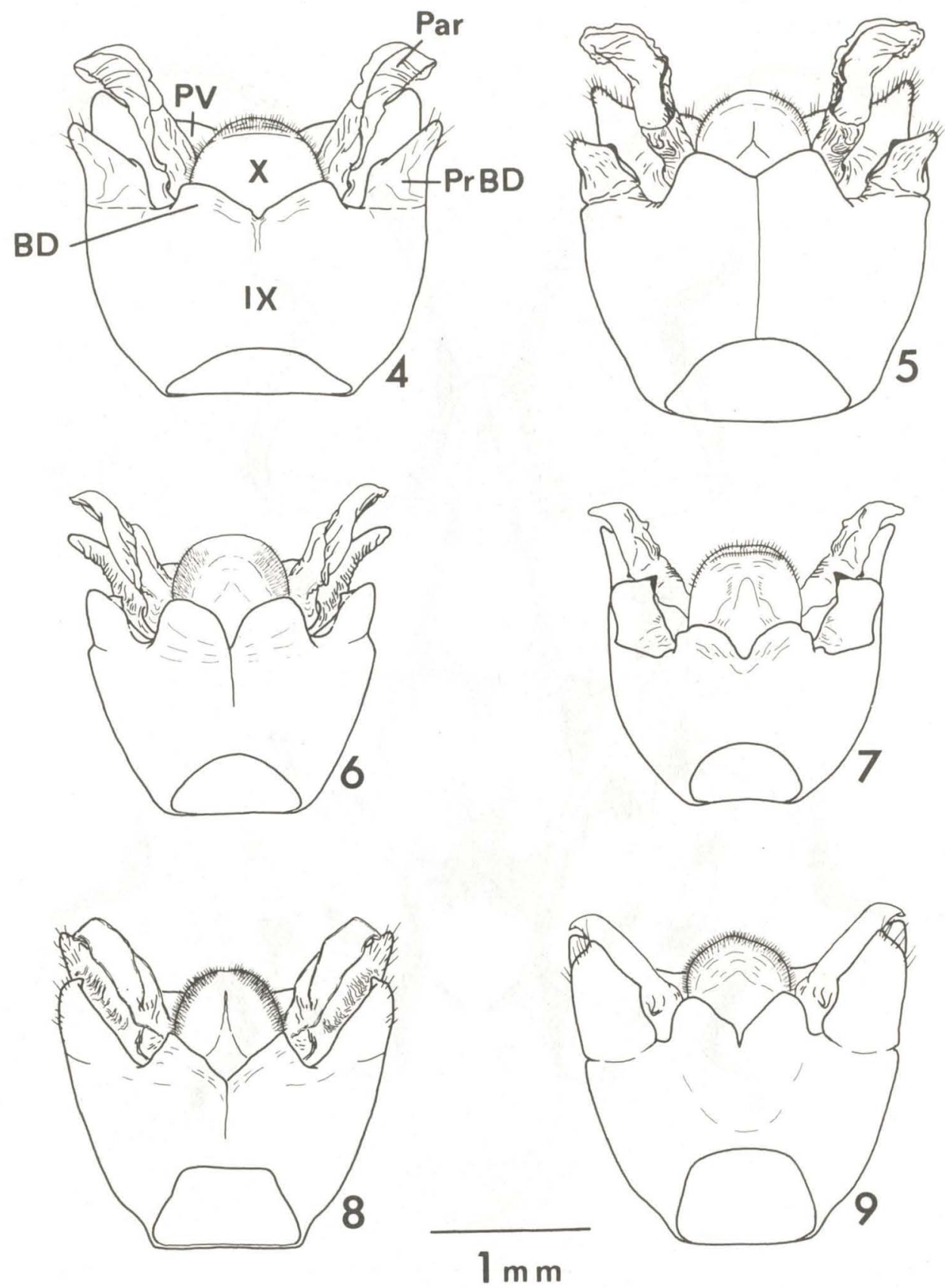

Pigóforo, vista dorsal - Fig. 4 - Dinocoris (D.) variolosus (Linnaeus, 1758) $(\mathrm{BD}=$ bordo dorsal, $\mathrm{Par}=$ parâmero, $\mathrm{PrBD}=$ projeções do bordo dorsal, $\mathrm{PV}=$ parede ventral, $\mathrm{IX}=9 .^{\circ}$ segmento, $\mathrm{X}=$ proctiger); Fig. $5-D$. (D.) antennatus (Dallas, 1851); Fig. $6-D$. (D.) maculatus (Laporte, 1832); Fig. 7 - D. (D.) reticulatus, sp. n.; Fig. $8-D$. (D.) corrosus (Herrich-Schaeffer, 1844); Fig. $9-$ D. (D.) rufitarsus Ruckes, 1958. 

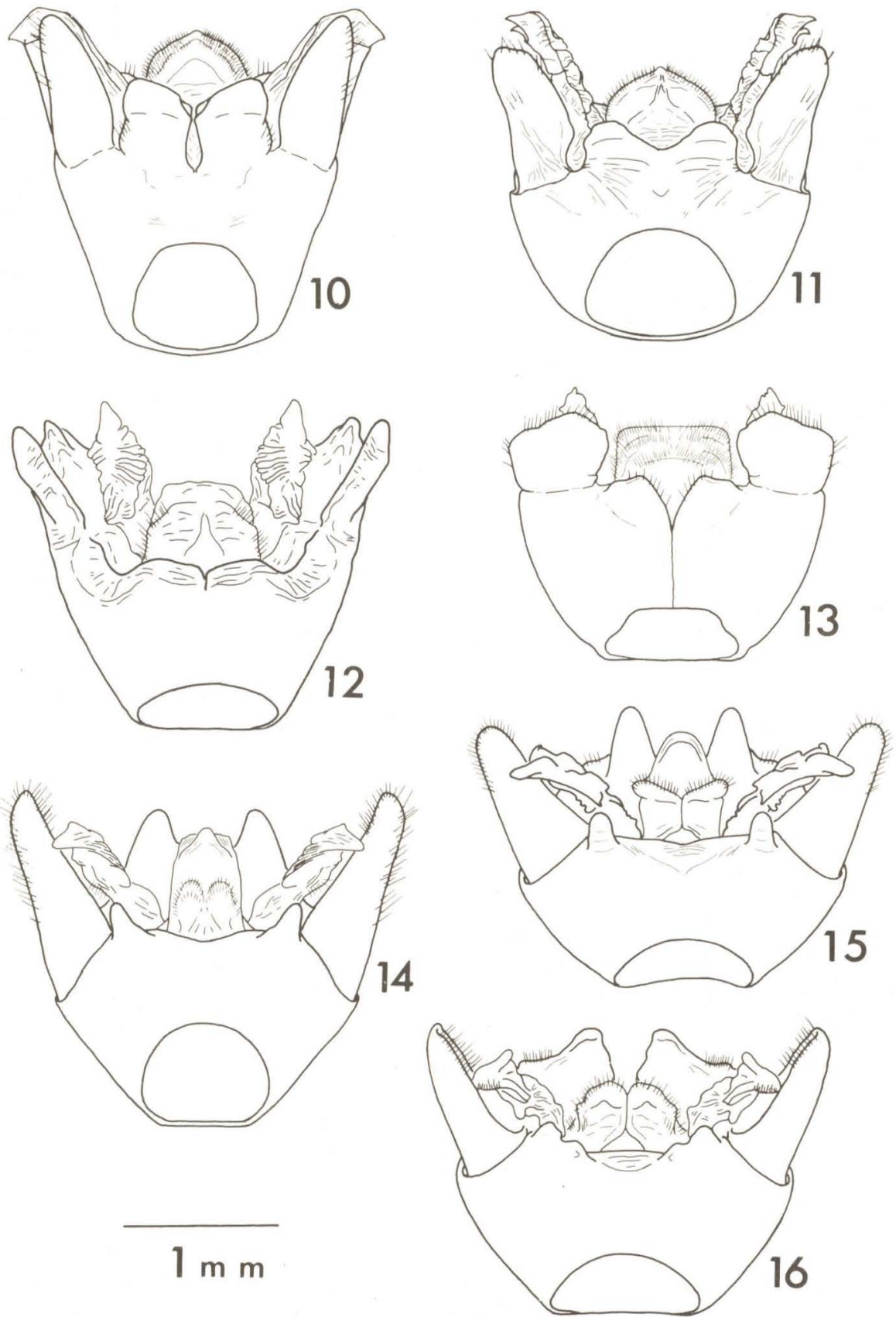

Pigóforo, vista dorsal - Fig. 10 - Dinocoris (D.) gibbosus (Fallou, 1889); Fig. 11 - D. (D.) ramosus (Walker, 1868); Fig. 12 - D. (D.) fabricii, sp. n.; Fig. $13-D$. (D.) gibbus (Dallas, 1852); Fig. $14-D$. (P.) lineatus (Dallas, 1852); Fig. $15-$ D. (P.) prolineatus, sp. n.; Fig. $16-D$. (P.) nigrodecoratus, sp. $\mathrm{n}$. 

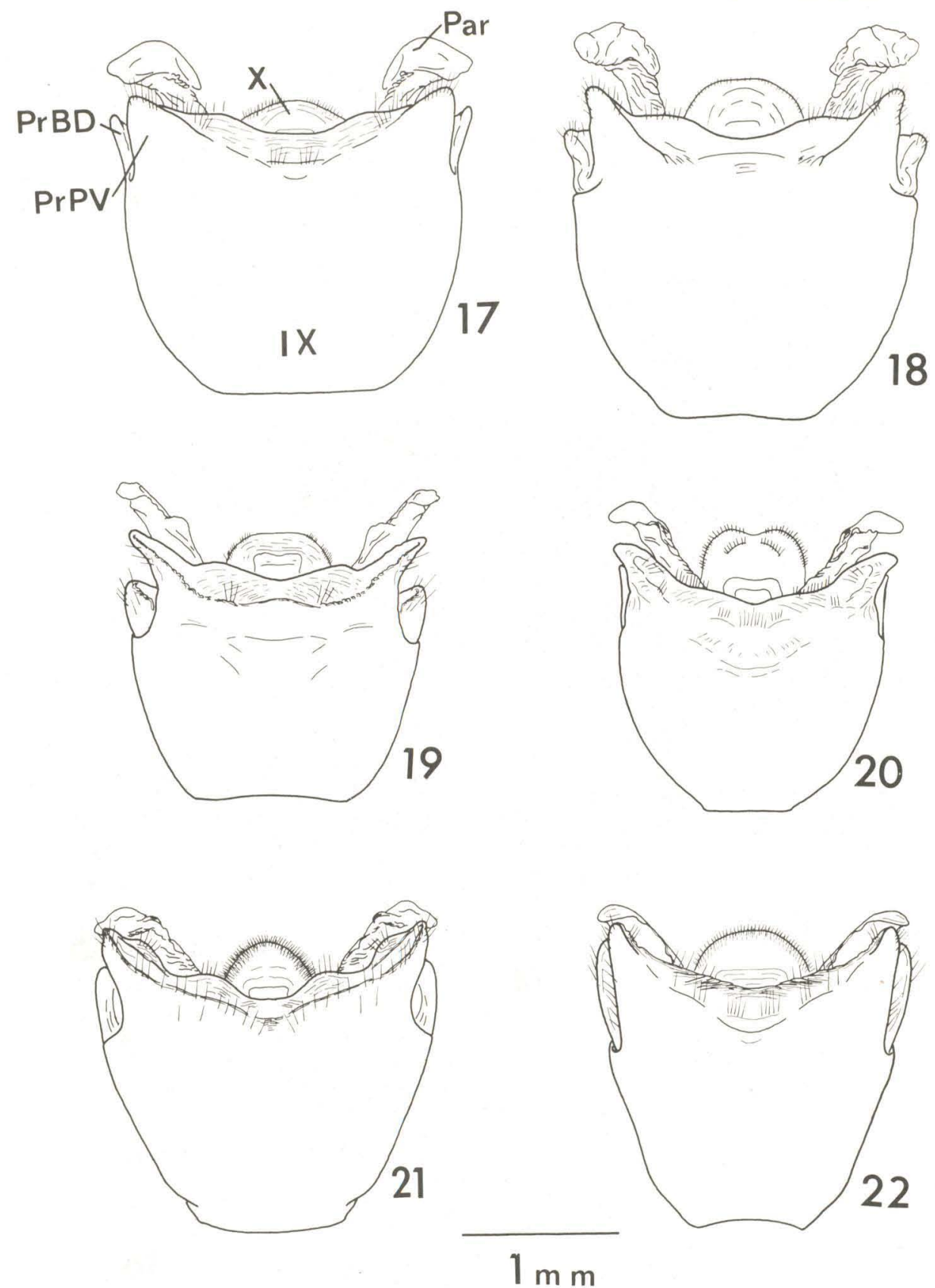

Pigóforo, vista ventral - Fig. 17 - Dinocoris (D.) variolosus (Linnaeus, 1758) $($ Par $=$ parâmero, $\operatorname{PrBD}=$ projeções do bordo dorsal, $\operatorname{PrPV}=$ projeções da parede ventral, $\mathrm{PV}=$ parede ventral, $\mathrm{IX}=90^{\circ}$ segmento, $\mathrm{X}=$ proctiger); Fig. $18-$ D. (D.) antennatus (Dallas, 1851); Fig. $19-$ D. (D.) maculatus (Laporte, 1832); Fig. $20-$ D. (D.) reticulatus, sp. n.; F'g. 21 D. (D.) corrosus (Herrich-Schaeffer, 1844); Fig. $22-$ D. (D.) rufitarsus Ruckes, 1958. 

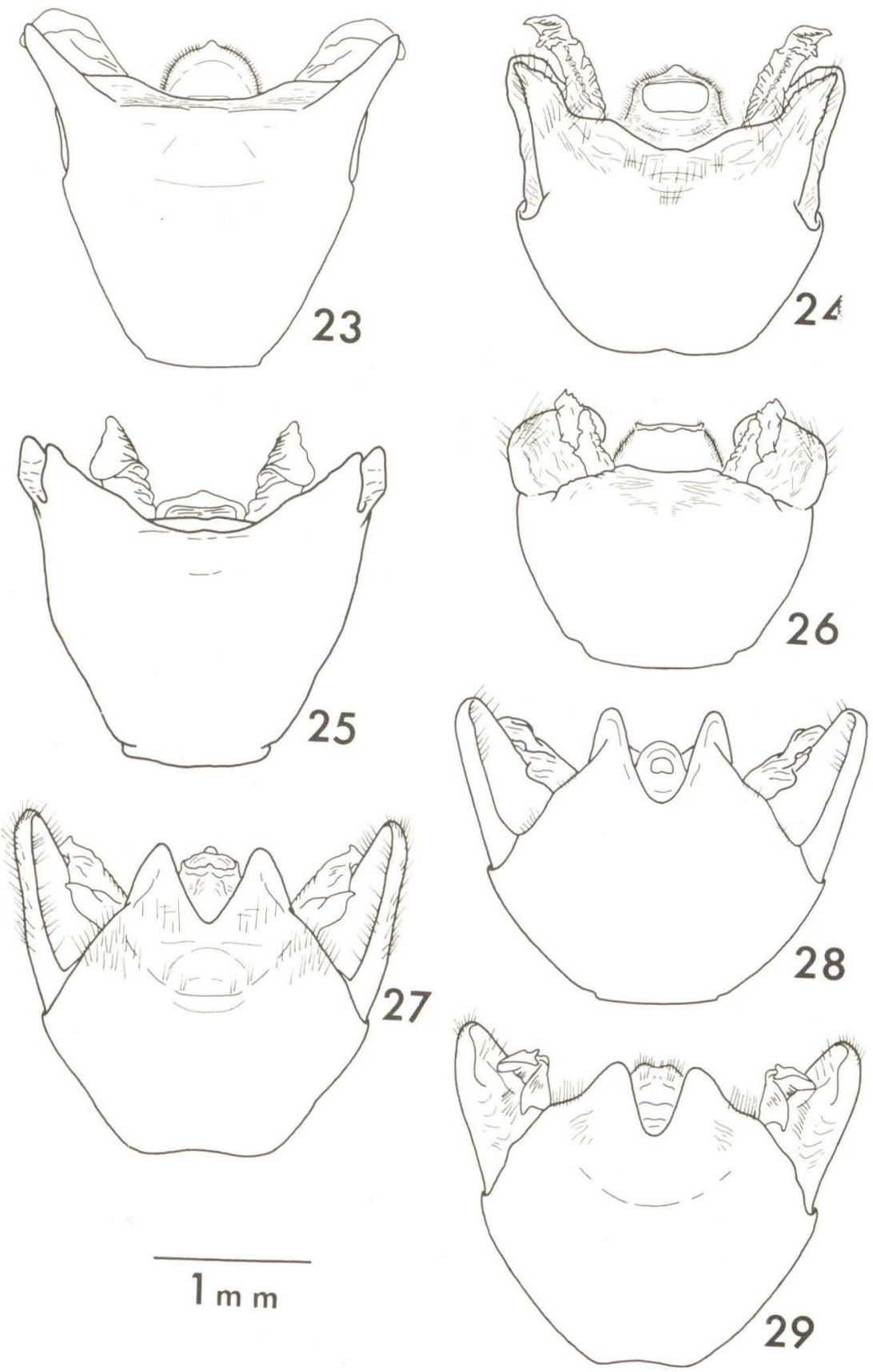

Pigóforo, vista ventrai - Fig. 23 - Dinocoris (D.) gibbosus (Fallou, 1889); Fig. $24-D$. (D.) ramosus (Walker, 1868); Fig. $25-D$. (D.) fabricii, sp. n.; Fig. 26 - D. (D.) gibbus (Dallas, 1852); Fig. $27-$ D. (P.) lineatus (Dallas, 1852); Fig. $28-$ D. (P.) prolineatus, sp. n.; Fig. $29-D$. (P.) nigrodecoratus, sp. $\mathrm{n}$. 


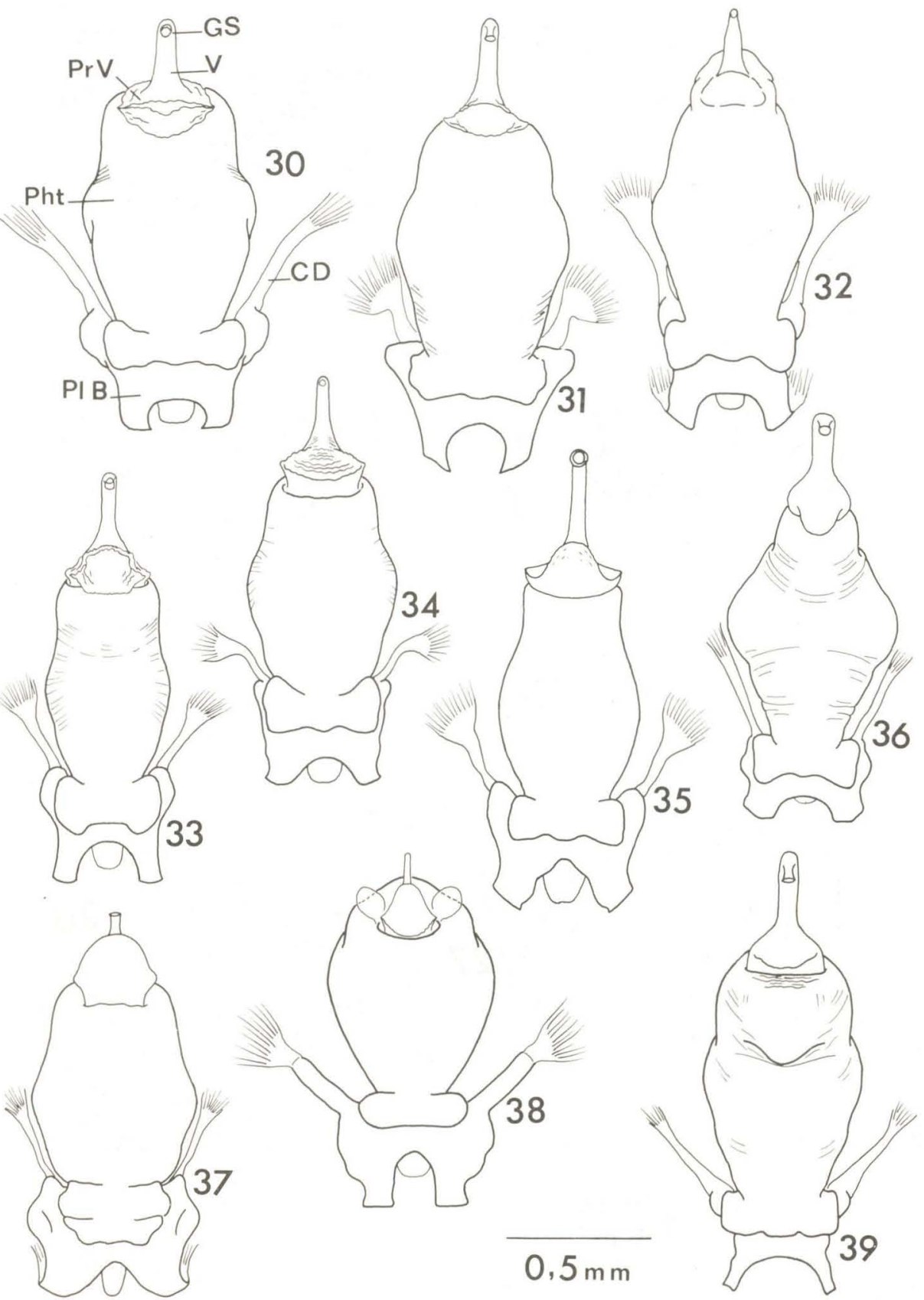

Phallus, vista dorsal - Fig. 30 - Dinocoris (D.) variolosus (Linnaeus, 1758) (CD = conetivo dorsal, $\mathrm{GS}=$ gonóporo secundário, $\mathrm{Pht}=$ phallotheca, $\mathrm{PIB}=$ placas basais, $\mathrm{Pr} \mathrm{Ph}=$ processus phallothecae, $\mathrm{PrV}=$ processus vesicae, $\mathrm{V}=$ vésica); Fig. $31-D$. (D.) antennatus (Dallas, 1851); Fig. 32 - D. (D.) corrosus (Herrich-Schaeffer, 1844); Fig. 33 - D. (D) reticulatus, sp. n.; Fig. $34-D$. (D.) maculatus (Laporte, 1832); Fig. $35-D$. (D.) rufitarsus Ruckes, 1958; Fig. $36-$ D. (D.) gibbosus (Fallou, 1889); Fig. $37-$ D. (D.) gibbus (Dallas, 1852); Fig. $38-D$. (D.) fabricii, sp. n.; Fig. $39-$ D. (D.) ramosus (Walker, 1868). 


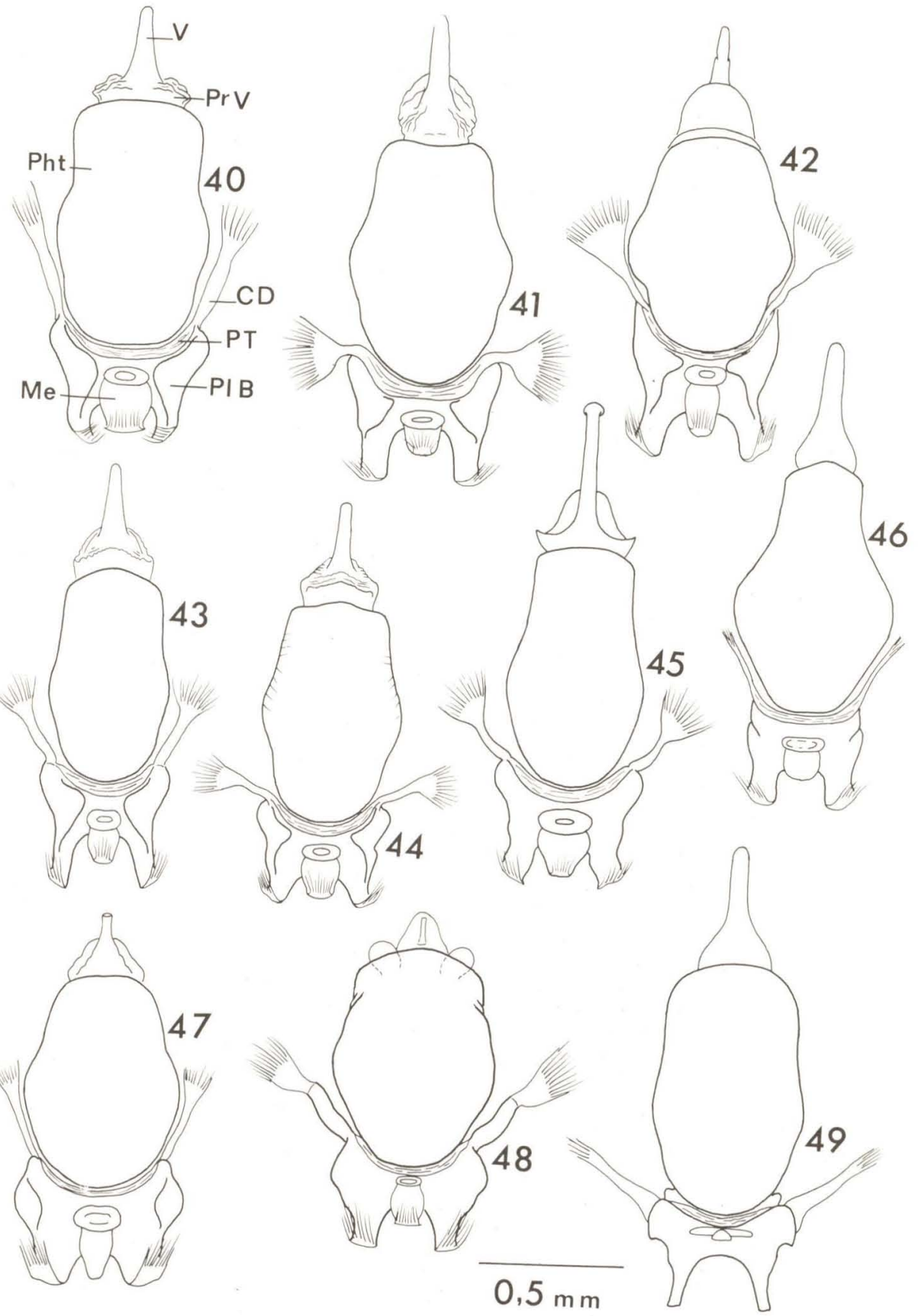

Phallus, vista ventral - Fig. $40-$ D. (D.) variolosus (Linnaeus, 1758) $(\mathrm{CD}=$ conetivos dorsais: $\mathrm{Me}=$ Membranblase $: \mathrm{PIB}=$ placas basais, Pht - phallotheca, $\mathrm{PrV}=$ processu.s vesicae, $\mathrm{PT}=$ ponticulus transversalis, $\mathrm{V}=$ vésica); Fig. $41-D$. (D.) antennatus (Dallas, 1851); Fig. $42-$ D. (D.) corrosus (Herrich-Schaeffer, 1844); Fig. $43-$ D. (D.) reticulatus, sp. n.; Fig. $44-$ D. (D.) maculatus (Laporte, 1832); Fig. $45-$ D. (D.) rufitarsus Ruckes. 1958; Fig. $46-$ D. (D.) gibbosus (Fallou, 1889); Fig. $47-$ D. (D.) gibbus (Dallas, 1852); Fig. 48 - D. (D.) fabricii, sp. n.: Fig. $49-$ D. (D.) ramosus (Walker, 1868). 
Coloração ocre-amarelada com puncturações ferrugíneas no pronoto $\mathrm{e}$ calosidade basal do escutelo. Junto aos ângulos póstero-laterais das cicatrizes do pronoto, situa-se um calo sub-arredondado, de coloração amarelada e briIhante.

Antenas ocre-amareladas com anéis negros ocupando o terço apical do segundo artículo e os três quartos apicais do terceiro e quarto artículos; às vezes, a base do segundo artículo apresenta uma mancha escura, esfumaçada.

Pronoto: Projeção triangular do ápice posterior das margens ântero-laterais duas vezes maior do que as projeções dos ângulos ântero-laterais. Peritrema ostiolar elevado, ocupando um terço da margem anterior da área evaporatória metapleural.

Escutelo: pontuações ferrugíneas maiores que as do cório sobre os dois terços posteriores do escutelo, isoladas e irregularmente distribuídas; ápice subtruncado de cada lado. Cório densamente coberto por fina pontuação ferrugínea, as vezes confluente porém não formando faixas transversais. Conexivo com uma faixa irregular ferrugínea junto às margens anterior e posterior de cada segmento.

Abdome com a superfície ventral ocre-amarelada, destituída de manchas escuras ou linhas ferrugíneas; espiráculos concolores.

Tíbia com uma mancha negra dorsal, sub-apical e um anel incompleto escuro no terço basal. Tarsos concolores.

Macho: Comprimento total 13,98 (12,92 - 14,59); largura do pronoto 6,97 $(6,99$ - 8,2); largura do abdome 8,81 (7,9 - 9,42).

Genitália do macho: Projeções dorso-laterais do pigóforo em curta aba, de contorno quase quadrangular em vista lateral, na base incompletamente destacada do corpo do pigóforo. Projeções látero-ventrais do pigóforo obtusas, em vista lateral atingindo o mesmo nível que as projeções dorso-laterais, entre elas um hiato em estreito "V". Quando o pigóforo é observado em vista dorsal, os parâmeros apresentam uma face em rasa meia-lua formada por duas carenas percurrentes, situados no mesmo plano. Quando o pigóforo é observado em vista posterior, o parâmero se apresenta em língua distendida, irregular, truncado no ápice, limitado de um lado pela carena que aparece em vista dorsal e, de outro, por uma terceira carena, ambas com ondulações (figs. 4 e 17). Phallus: Processo da vésica com lábio saliente, pregueamentos restritos ao lábio. Após o processo, curso da vésica a meio caminho sofrendo inflexão de quase $90^{\circ}$; gonóporo secundário voltado para a face dorsal (figs. 30,40 e 56).

Fêmea: Comprimento total 15,2; largura do pronoto 7,9.

Genitália da fêmea: Placas genitais conforme ilustrado na figura 71 . Receptaculum seminis: Capsula seminalis em forma de dedo, com diâmetro e comprimento aproximadamente duas vezes maior do que a pars intermedialis; porção do ductus posterior à área vesicular com pregueamentos e maior diâmetro em seus dois terços distais, comprimento correspondendo a pouco mais que um terço da porção do ductus anterior à área vesicular; Chitinellipsen presentes (Fig. 84).

Material examinado: Macho e fêmea com as etiquetas: (a) "Type" (b) "S. america/44 98" (c) "a" (d) Dinidor antennatus (Type) Dallas" (e) "BRIT. MUS. TYPE No. HEM. 683".

PANAMA: macho - Las Cambres, 9०06'N 79032'W, 31/I/1974, armadilha de luz, H. Wolda, INPA; Canal Zone: fêmea - Barro Colorado Isl., 28-30/IV/1964, WD \& SSDuckworth, NMNH.

TRINIDAD: macho - Simla, 6/III/1950, W. M. Beebe, AMNH.

GUIANA FRANCESA: 2 machos e 1 fêmea - Kourou, IV/1909, Coll. A. Bonhouré, MP; 2 fêmeas - Les Roches de Kourou, 1907, E. Le Moult, MP; fêmea - s/ localidade, 1899, R. Oberthür, Coll. BAR, MP.

Diagnose diferencial: Esta espécie se aproxima de $D$. histrio, $D$. antennatus e $D$. maculatus pelo tamanho e coloração da superfície dorsal. Distingue-se de $D$. histrio e $D$. antennatus por não apresentar faixas transversais no disco do cório e de $D$. maculatus por não apresentar a mancha ferrugínea no ápice 
da veia radial. Distingue-se facilmente de todas as espécies por apresentar o abdome totalmente ocre-amarelado, destituído de manchas ferrugíneas.

Dinocoris (Dinocoris) histrio (Linnaeus, 1758) (Figs. 73 e 88 )

Cimex histrio Linnaeus, 1758: 442; 1767: 717; Gmelin, 1788: 2133.

Cimex peregrinator Linnaeus, 1758: 444; 1764: 173; 1767: 721; Goeze, 1778: 186; Gmelin, 1788: 2133. Localidade tipo: "Indies".

Empicoris peregrinator; Stal, 1866: 155; 1872: 11; Lethierry \& Severin, 1893:

89; Kirkaldy, 1909: 220.

Localidade tipo: "Indiis".

Tipo: depositado em Upsala (Ruckes, in litt.) maior.

Semelhante a $D$. nigroantennatus na coloração da superfície dorsal, porém

Caracteriza-se principalmente por apresentar uma faixa transversal de pontuações ferrugíneas sobre o disco do cório, que se estende sobre o escutelo; pontuações ferrugíneas concentradas na base do cório e clavus, além de formar uma mancha sub-arredondada no endocório, adjacente ao meio do clavus. Demais áreas ocre-amareladas do cório e escutelo totalmente destituídas de pontuações.

As margens ântero-laterais do pronoto formam com os ângulos umerais um ângulo de $90^{\circ}$.

No abdome, as faixas de pontuações ferrugíneas nas margens anterior e posterior dos segmentos do conexivo repetem-se por igual na superfície ventral.

Peritrema ostiolar obsoleto, evanescente a partir da abertura das glândulas odoríferas.

Pernas ocre-avermelhadas, com duas manchas negras nas tíbias, uma no terço basal e outra no terço apical e uma terceira mancha mais próxima do ápice dos fêmures; metade apical do terceiro artículo tarsal negra.

Fêmea: Comprimento total 15,96; largura do pronoto 8,88; largura abdominal 10,86 .

Genitália da fêmea: Placas genitais conforme ilustrado na figura 73. Receptaculum seminis: Crista anular posterior pouco destacada da capsula seminalis, conferindo ao conjunto o aspecto de um bulbo com uma aba basal; porção do ductus posterior à área vesicular com diâmetro irregular e comprimento pouco menos que dois terços da porção do ductus anterior à área vesicular; Chitinellipsen presentes (Fig. 88).

Material examinado: GUIANA: Mazaruni Potaro: fêmea - Tumatumari, Rio Potaro, IV/1912. J. R. de la Torre Bueno, Collection K. U., SEM.

Observações: As referências de Pennington (1920) e Bosq (1937) desta espécie para a Argentina e de Pirán (1956) para o Uruguai, tratam-se, certamente, de um erro de identificação.

Diagnose diferencial: Além de se aproximar de D. nigroantennatus, aproxima-se também de $D$. antennatus pela presença da faixa transversal no disco do cório, porém apenas em $D$. histrio e $D$. antennatus esta faixa se continua sobre o escutelo. Distingue-se de $D$. antennatus por apresentar as áreas ocreamareladas do cório e escutelo totalmente destituídas de pontuações e, também, pela coloração da superfície ventral do abdome.

Dinocoris (Dinocoris) maculatus Laporte, 1832

(Figs. 6, 19, 34, 44, 59, 72, 87)

Halys vıriolosa Fabricius, 1803: 182; Zimsen, 1964: 319.

Dinidor r.zaculatus Laporte, 1832: 64, est. 55, fig. 1; Amyot \& Serville, 1843:

111. L ocalidade tipo: "Brésil".

Dinocoris maculatus; Burmeister, 1835: 363; Stal, 1868: 20; Becker \& Grazia-

Vieira, 1971: 23. 
Empicoris maculatus; Herrich-Schaeffer, 1844: 44-45; Erichson, 1848: 609;

Stal, 1872: 11; Lethierry \& Severin, 1893: 89; Kirkaldy, 1909: 220.

Dinidor variolosus; Dallas, 1851: 166.

Localidade tipo: "America Meridionalis", aqui restrita ao Pico do Corcovado, Rio de Janeiro, Estado do Rio de Janeiro, Brasil.

Tipo: Não designado originalmente. $\mathrm{Na}$ coleção do ZM existem cinco exemplares pertencentes à coleção original de Fabricius; Zimsen (1964) cita mais um exemplar, em Kiel. Pelo exame do material do ZM verificamos que duas fêmeas correspondem à descrição original de $H$. variolosa e acreditamos ter sido o material examinado por Stal (1868) quando este autor considerou $D$. maculatus Laporte como um sinônimo junior de $H$. variolosa.

Uma das demais fêmeas concorda com a descrição de D. gibbosus, a fêmea restante concorda com a descrição de. D. antennatus e, finalmente, o macho constitui uma nova espécie -descrita adiante, neste trabalho. $\mathrm{Na}$ descrição original de $H$. variolosa não há nada que indique o número de exemplares em que foi baseada, nem de que tenha sido mais do que um único exemplar. Tendo em vista a necessidade de fixar o conceito de variolosa, consideramos uma das fêmeas que corresponde à descrição original como sendo o holótipo e como tal a assinalamos.

Coloração geral testácea, escurecida em alguns exemplares, sobre a qual se destacam as densas puncturações negro-ferrugíneas no pronoto e calosidade basal do escutelo.

Antenas predominantemente escuras, incluindo os tubérculos anteníferos que são externamente maculados de negro; primeiro artículo amarelado, manchado irregularmente de negro; segundo artículo com o terço basal amarelado, também manchado irregularmente de negro, com os dois terços apicais negros; um estreito anel basal amarelado no terceiro e quarto artículos, o restante de coloração negra. A extensão da área negra no segundo artículo antenal é variável.

Pronoto: Ápice das margens ântero-laterais com inconspícuas projeções triangulares. Às vezes estão presentes manchas ocre-alaranjadas sobre as áreas subcalosas do pronoto e escutelo. Peritrema ostiolar como em $D$. variolosus. Ápice do escutelo arredondado e de cada lado da linha média longitudinal manchado de negro. Cório quase inteiramente testáceo, apresentando uma mancha negro-ferrugínea no ápice da veia radial e uma concentração de pontuações na base da costa.

Segmentos do conexivo com uma faixa de pontuações ferrugíneas anterior e outra posterior que se continuam na superfície ventral formando aí uma cunha. Espiráculos ferrugíneos.

Pernas testáceas com um par de nítidas manchas negras nas tíbias, formari do anéis incompletos, um no ápice e outro mais próximo da base; uma únic: mancha negra, nos fêmures, quase junto ao ápice; tarso com a metade poste rior do terceiro artículo de coloração negra.

Macho: Comprimento total 13,45 (13,22 - 13,68); largura do pronot 7,29; largura abdominal $8,43(8,36-8,51)$.

Genitália do macho: Bordo dorsal do pigóforo projetado por sobre $\mathrm{X}$ segmento, fendido no meio e apresentando linha de "sutura" que percor! meio caminho até a abertura basal do pigóforo; projeções dorso-laterai: quando em vista lateral, de contorno quase retangular, mais largas do qu longas; bordo dorso-distal dobrado em ponta em direção ao centro do pigc foro; base das expansões incompletamente destacadas do corpo do pigóforo Projeções da margem ventral do pigóforo recurvas para fora, em vista lateral ultrapassando em dobro o comprimento das projeções dorso-laterais, na base contíguas a estas, sem deixar hiato ao longo do plano frontal do pigóforo. Quando o pigóforo é observado em vista dorsal: parâmeros, no primeiro plano, com uma área em rasa meia lua, determinada por duas carenas percurrentes no mesmo plano; quando o pigóforo é observado em vista posterior: parâmetros em língua distendida, a metade basal da "língua" com o dobro da largura da distal, pois a carena do lado ventral reentra bruscamente, em ângulo quase reto, nesta altura (figs. 6 e 19). Phallus: Processo da vésica em 
colarinho liso no lado ventral; no lado dorsal projetado em lábio com leves pregueamentos; após o processo, curso da vésica em curto "S" muito aberto; gonóporo secundário abrindo-se dorso-posteriormente (Figs. 34, 44 e 59).

Fêmea: Comprimento total 15,92 (15,5 - 16,56); largura do pronoto 8,42 $(7,9$ - 8,96); largura abdominal 9,91 (9,42 - 10,64).

Genitália da fêmea: Placas genitais conforme ilustrado na figura 72 . Receptaculum seminis: capsula seminalis tão longa quanto a pars intermedialis, as duas juntas quase tão longas quanto a região do ductus posterior à área vesicular; porção do ductus anterior à área vesicular pouco mais longa que a porção do ductus posterior à área vesicular (Fig. 87).

Material examinado: Holótipo fêmea de Halys variolosa Fabricius, com as seguintes etiquetas: (a) minúscula etiqueta verde (b) $\$$ (c) Type, depositado no ZM; fêmea, com as etiquetas (a) minúscula etiqueta verde (b) Type, depositada no ZM. 4 fêmeas - sem dados, 302/40, MP; macho - sem dados, 4197/34, MP; fêmea - sem dados, 35, MP; 2 fêmeas - sem dados, MP; 7 fêmeas - sem dados, MCN 2082, 2083, 2084, 2085, 2086, 2087, 2090; fêmea — sem dados, INPA; fêmea — sem dados, Mus. Westerm., ZM.

VENEZUELA: Distrito Federal: fêmea - El Valle, 20/III/1944, F. Fernandez Y., IZA; fêmea - Caracas, 19/VI/1935, C. G. Salazar, IZA; fêmea - Caracas, 9/II/1932, Martorell, AMNH. Aragua: fêmea - Maracay, 15/VIII/1935, D. A. Texera, IZA; fêmea - Rancho Grande, 1100 m, VIII/ 1966, F. Romero, IZA. Território Federal Delta Amacuro: fêmea - Caño Guayo, 30/XII/1960, R. Lichy \& A. Perez, IZA; fêmea - Winikina, 17/VIII/1954, CER, LS.

COLOMBIA: macho - sem dados, Mus. Westerm., ZM.

BRASIL: Amazonas: fêmea - Amazonas inferior, 384/80, RS; 2 fêmeas - Benjamin Constant, Pahl. DZRS e NMNH; fêmea - Benjamin Constant,

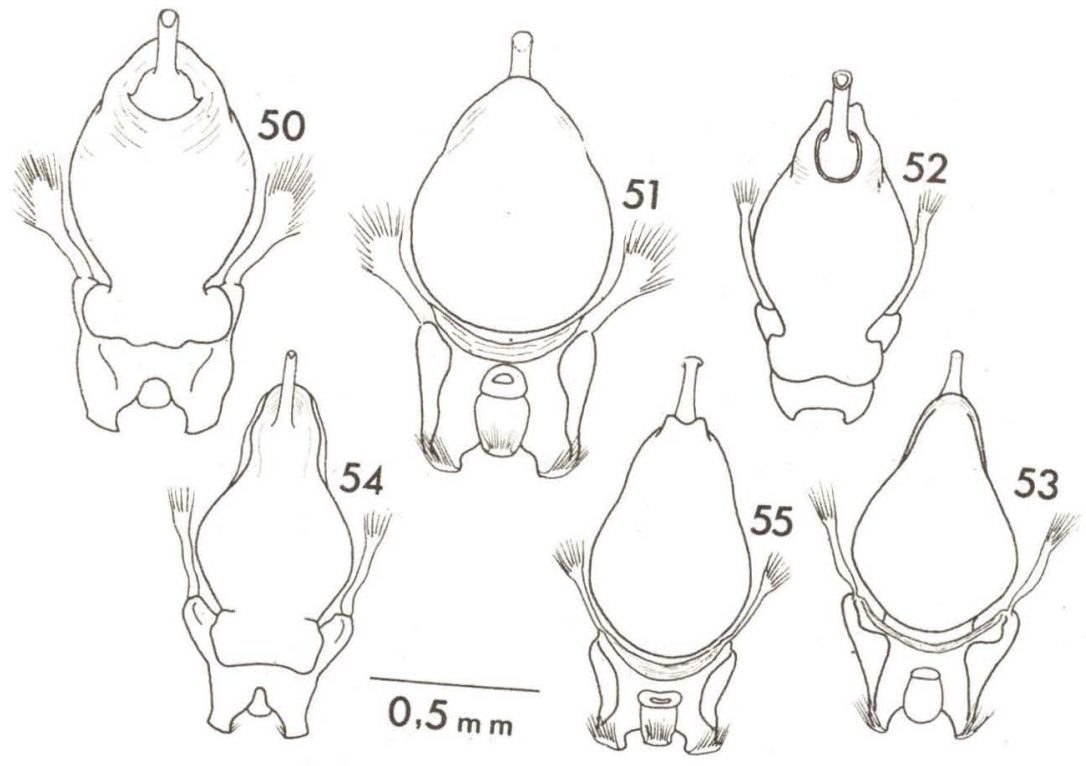

Phallus - vuruev..

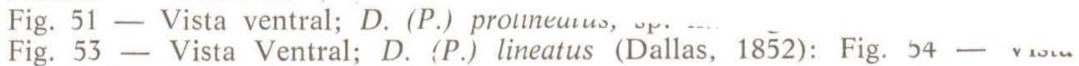
dorsal; Fig. 55 - Vista ventral. 


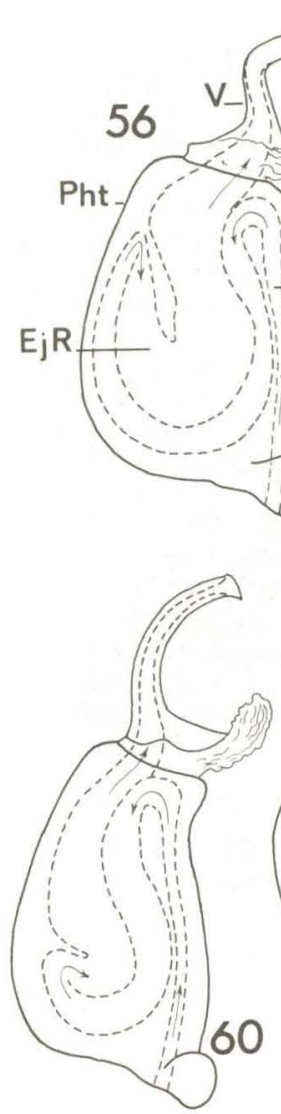

GS

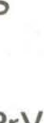



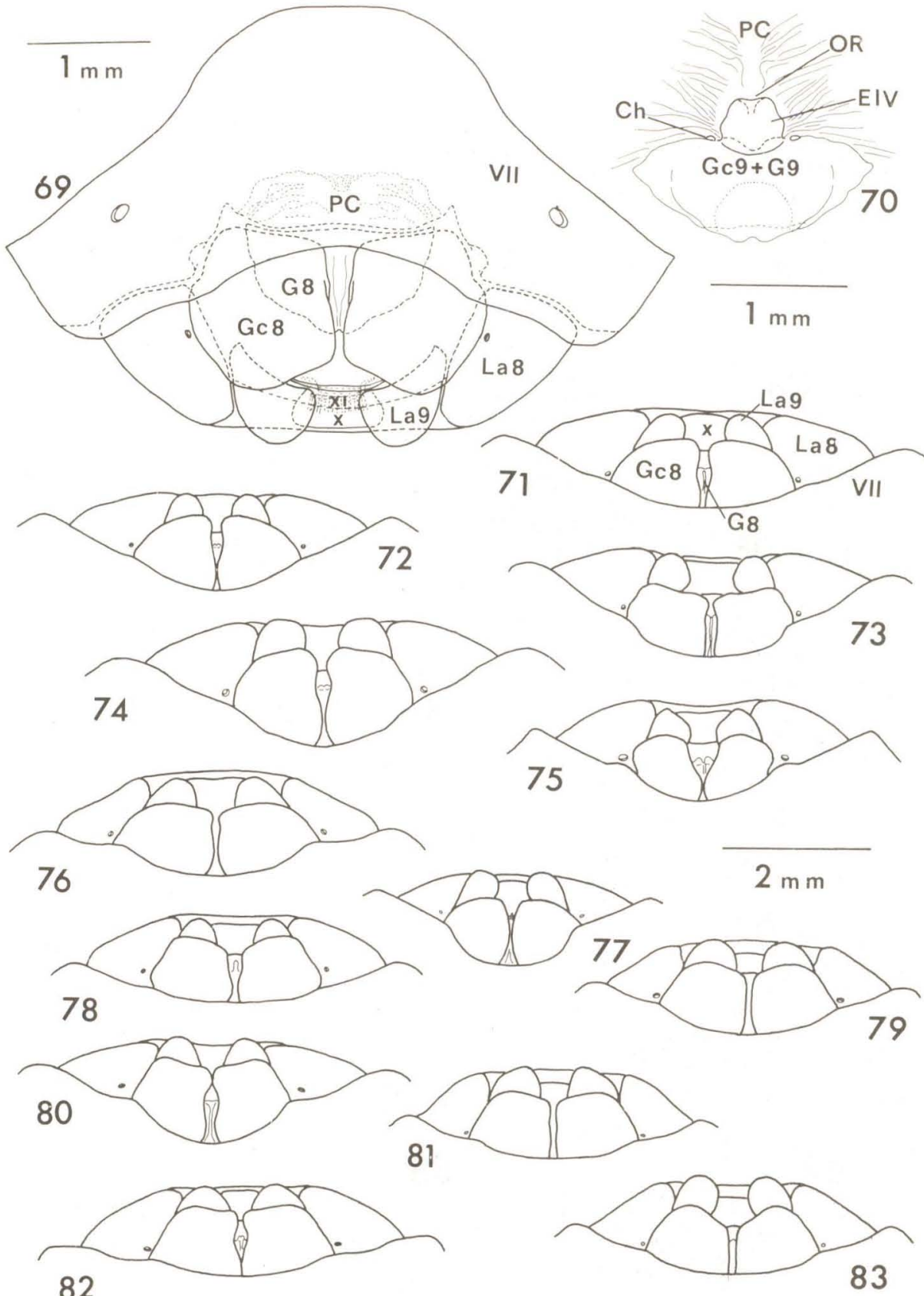

Fig. 69 - Dinocoris (P.) lineatus (Dallas, 1852), genitália externa da fêmea, placas genitais diafanizadas $(\mathrm{La} 8=$ laterotergito $8, \mathrm{La} 9=$ laterotergito $9, \mathrm{~GB}=$ gonapófises $8, \mathrm{Gc} 8=$ gonocoxito $8, \mathrm{PC}=$ pars communis, $\mathrm{VII}=7.0^{\circ}$ esternito, $\mathrm{X}=$ proctiger, $\mathrm{XI}=11 .^{\circ}$ segmento abdominal = ânus); Fig. $70-D$. (P.) lineatus (Dallas, 1852), gonocoxitos e gonapófises do 9. ${ }^{\circ}$ segmento abdominal, vista ventral $(\mathrm{Ch}=$ Chitinellipsen, $\mathrm{EIV}=$ espessamento da íntima vaginal, $\mathrm{G} 9=$ gonapófises $9, \mathrm{Gc} 9=$ gonacoxitos $9, \mathrm{OR}=$ orificium receptaculi, $\mathrm{PC}=$ pars communis). Genitália externa da fêmea, placas genitais a seco; Fig. 71 - D. (D.) variolosus (Linnaeus, 1758); Fig. 72 - D. (D.) maculatus (Laporte, 1832); Fig. 73 - D. (D.) histrio (Linnaeus, 1758); Fig. $74-$ D. (D.) antennatus (Dallas, 1851); Fig. 75 - D. (D.) gibbus (Dallas, 1852); Fig. $76-$ D. (D.) ramosus (Walker, 1868); Fig. $77-$ D. (D.) nigro antennatus, sp. n.; Fig. $78-D$. (D.) corrosus (Herrich-Schaeffer, 1844); Fig. $79-$ D. (P.) lineatus (Dallas, 1852); Fig. 80 - D. (D.) rufitarsus Ruckes, 1958; Fig. 81 - D. (P.) prolineatus, sp. n.; Fig. $82-$ D. (D.) gibbosus (Fallou, 1889); Fig. $83-$ D. (P.) nigrodecoratus, sp. n. 


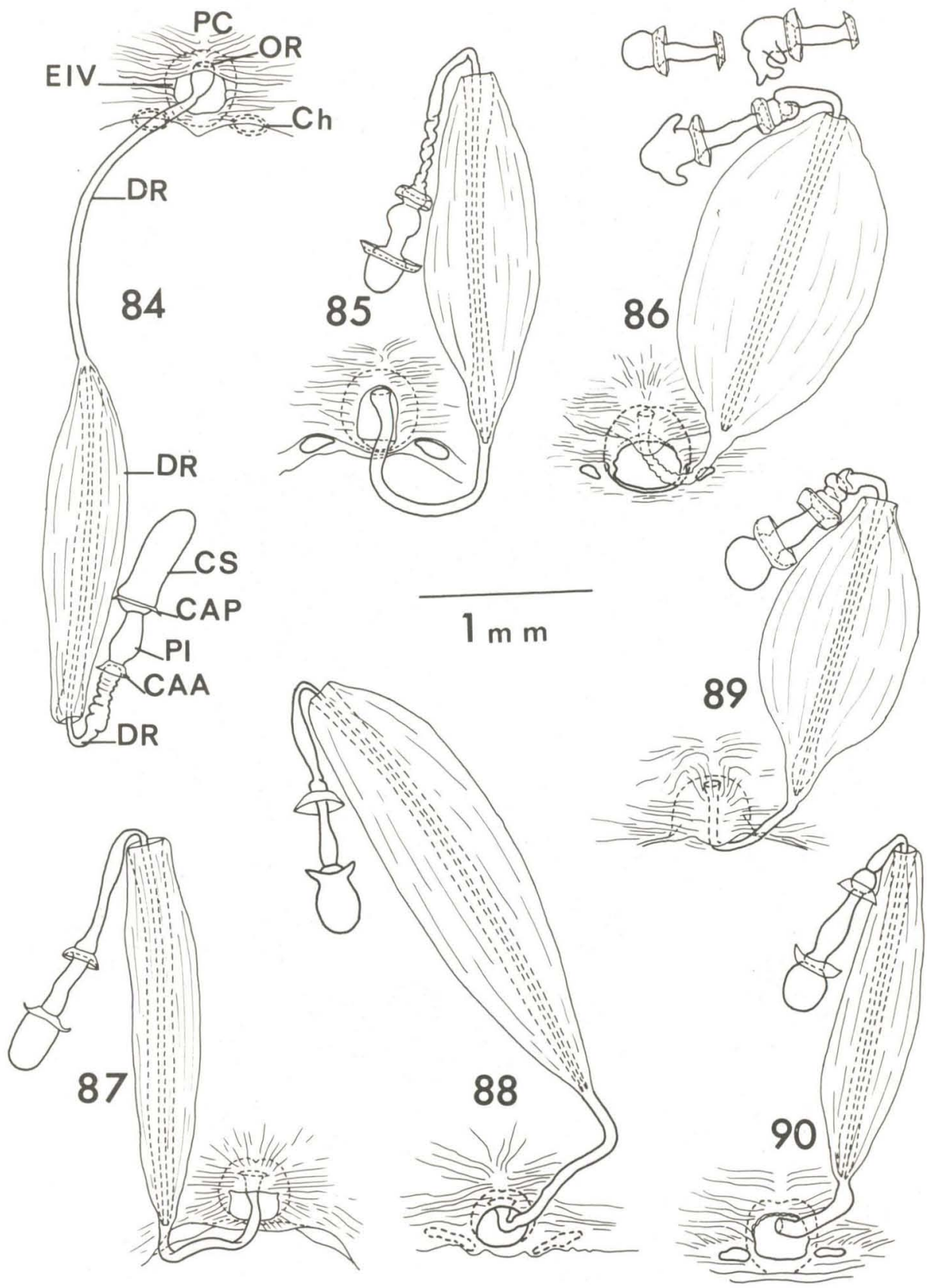

Vias genitais ectodérmicas. Fig. 84 - Dinocoris (D.) variolosus (Linnaeus, 1758) $(\mathrm{CAA}=$ crista anular anterior, CAP $=$ crista anular posterior, $\mathrm{Dh}=$ Chitinellipsen, $\mathrm{CS}=$ capsula seminalis, $\mathrm{DR}=$ ductus receptaculi, $\mathrm{EIV}=$ espessamento da íntima vagital, $\mathrm{OR}=$ orificium receptaculi, $\mathrm{PC}=$ pars communis, PI = pars intermedialis); Fig. $85-$ D. (D.) gibbosus (Fallou, 1889); Fig. 86 - D. (P.) lineatus (Dallas, 1852); Fig. 87 - D. (D.) maculatus (Laporte, 1832); Fig. $88-D$. (D.) histrio (Linnaeus, 1758; Fig. $89-D$. $(P$.$) prolineatus, sp. n.; Fig. 90-D$. (P.) nigrodecoratus, sp. n. 


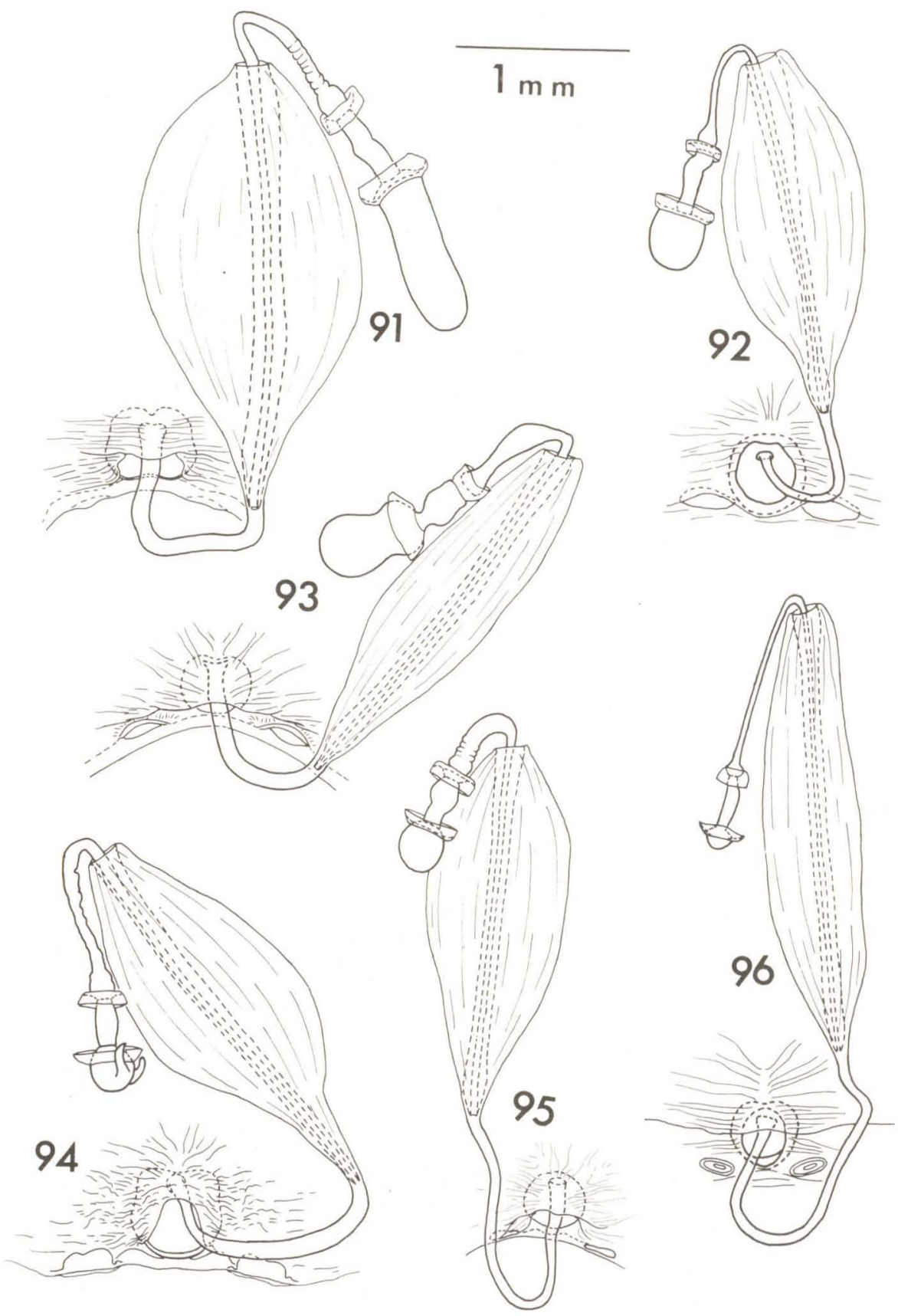

Vias genitais ectodérmicas. Fig. 91 - Dinocoris (D.) antennatus (Dallas, 1851); Fig. $92-D$. (D.) corrosus Herrich-Schaeffer, 1844); Fig. 93 - D. (D.) rufitarsus Ruckes, 1958; Fig. $94-D$. (D.) ramosus (Walker, 1868); Fig. 95 D. (D.) gibbus (Dallas, 1852); Fig. 96 - D. (D.) nigro antennatus, sp. n. 
Rio Javari, IV/1942, Dirings, MCN 2081; fêmea - Benjamin Constant, Rio Javari, 15/III a 15/IV/1942, Parko, MCN 2088; fêmea-Manacapuru S. A., Rio Solimões, IV/1926, S. M. Klages, SEM; fêmea - Alto Solimões, V/1940, A. R. Almeida, IOC. Pará: 3 fêmeas e macho - 18/VII/1920, H. S. Parish, AMNH; 2 fêmeas - 18/VI/1920, H. S. Parish, J. R. de la Torre Bueno, Coll. K. U., SEM; fêmea - Faz. Taperinha, próx. Santarém, 1-11/II/1968, Exp. Perm. Amaz., MZSP. Bahia: 3 fêmeas - Pedrito Silva leg., MCN 2080 e IB. Mato Grosso: fêmea - Reserva Humboldt, 2/X/1975, na luz, INPA; 2 fêmeas - Corumbá, XII/1917, E. Garbe, MZSP. Rio de Janeiro: macho - Rio de Janeiro, 8/VIII/1940, V. Picorelli, MN; fêmea - Corcovado, Rio de Janeiro, 1/XII/1966, Moure e Seabra, DZPR; fêmea - Corcovado, Rio de Janeiro, 3/XII/1965, Moure e Seabra, DZPR; fêmea - Corvocado, Rio de Janeiro, XI/1961, Moure e Seabra, DZPR. São Paulo: fêmea - Ubatuba, 22/IV/1968, P. C. Montouchet, MZSP; fêmea - Ubatuba, 27/X/1979, I. Pierozzi Jr., ZUEC 3602; fêmea - Ubatuba, 8/III/1978, B. Amaral F. ${ }^{\circ}$, ZUEC 976.

PERU: Loreto: macho - Yarina Cochas, Rio Ucayali, 5/X/1946, Weyrauch, DZRS.

Diagnose diferencial: A mancha negro-ferrugínea, no ápice da veia radial, destaca-se sobre a coloração testácea do cório, permitindo um fácil reconhecimento de $D$. maculatus, distinguindo-a das demais espécies.

Dinocoris (Dinocoris) corrosus (Herrich-Schaeffer, 1844)

(Figs. 8, 21, 32, 42, 64, 78, 92)

Epicoris corrosus Herrich-Schaeffer, 1844: 46, fig. 732; Stal, 1872: 11; Lethierry \& Severin, 1893: 88.

Dinidor corrosus; Dallas, 1851: 166; Walker, 1867: 200.

Dinocoris binotata Ruckes, 1958: 6. Localidade tipo: Nova Teutônia, Santa Catarina, Brasil.

Dinocoris corrosus; Piran, 1962: 6.

Localidade tipo: Paraguai, mencionado na descrição original.

Tipo: holótipo macho (Ruckes, in litt); originalmente depositado no Zoologische Museum, Munich. Não localizado, em 1983, pelo curador desta coleção.

Coloração geral ocre-amarelada, com uma forma típica largamente ovalada.

Antenas ocre-amareladas com anéis negros que ocupam o terço apical do segundo artículo, os três quartos apicais do terceiro e a metade do quarto artículo, além das pontuações negras no primeiro e segundo artículos.

Pronoto, escutelo e cório com pontuações irregularmente distribuídas, formando inúmeros sulcos que conferem à superfície dorsal um aspecto corrugado. A forma do pronoto é como em D. histrio; uma faixa calosa, irregular, de coloração ocre-amarelada ou avermelhada, disposta junto à margem posterior das cicatrizes. Esta coloração avermelhada pode estar presente nos calos basais do escutelo; pontuações ferrugíneas, maiores e mais grosseiras, presentes no lado interno dos calos. Peritrema ostiolar elevado e ocupando a metade da margem anterior da área evaporatória da metapleura. Ápice do escutelo vagamente refletido.

Conexivo com três faixas transversais de pontuações, sendo uma central, inconspícua em alguns exemplares, outra mais próxima da margem anterior e a terceira mais próxima da margem posterior de cada segmento. Margens laterais do abdome, na superfície ventral, com pontuações ferrugíneas, além de semi-círculos dispostos como se delimitassem os segmentos do conexivo.

Pernas com pontuações grosseiras, ferrugíneas, sobre as tíbias e fêmures; às vezes, uma mancha negro-ferrugínea pré-apical nas tíbias e nos fêmures. Tarsos com o primeiro artículo e mais da metade do terceiro de coloração negro-ferrugínea.

Macho: Comprimento total 11,43 (10,94 - 12,16); largura do produto 6,23 $(6,08-6,68)$; largura abdominal $8,05(7,14-8,47)$. 
Genitália do macho: Projeções dorso-laterais do pigóforo de contorno triangular quando em vista lateral, ápice com pequena ponta voltada para a face ventral do pigóforo. Bordo dorsal do pigóforo pouco expandido sobre os lados do X segmento, no meio com largo recorte em "V" aberto, da extremidade do qual segue uma linha de "sutura" que percorre o pigóforo até quase sua abertura basal. Margem ventral nitidamente bi-sinuada. Em vista lateral, "hiato" em gota estreita e pouco funda entre as projeções dorsais e ventrais do pigóforo. Quando observados no pigóforo em vista dorsal, os parâmeros são inteiramente visíveis entre o X segmento e as expansões dorsolaterais, no primeiro plano em arco de circunferência, com bordos limitados por carenas. Quando observados no pigóforo em vista posterior, os parâmeros apresentam-se em língua estendida, de bordos carenados, o do lado ventral, na metade basal, formando uma projeção triangular (figs. 8 e 21). Phallus: limite phallotheca-vésica pouco nítido, incompleto. Processo da vésica em alto colarinho no lado ventral e em projeção menor no lado dorsal; área tubular da vésica partindo da posição intermediária entre elas, em tubo curto, fino em relação às demais espécies do subgênero (figs. 32, 42 e 64).

Fêmea - Comprimento total 13,71 (12,61 - 14,44); largura do pronoto 7,02 (6,53 - 7,44); largura abdominal 8,93 (8,36 - 9,57).

Genitália da fêmea: Placas genitais conforme ilustrado na figura 78. Receptaculum seminis: Capsula seminalis quase tão longa quanto a pars intermedialis; porção do ductus posterior à área vesicular com diâmetro bem menor que a pars intermedialis e quase tão longa quanto a porção do ductus anterior à área vesicular. Chitinellipsen presentes (fig. 92).

Material examinado: fêmea — sem dados, Stal, 381/80, RS.

BRASIL: São Paulo: macho - Campinas, L. Simmelink, ZUEC 974. Santa Catarina: macho e fêmea - Nova Teutônia, 5/XI/1934, F. Plaumann, Dinocoris binotata Ruckes, Holotype e Alotype, respectivamente, AMNH; macho e fêmea - Ibidem, Parátipos; 3 machos e 9 fêmeas - Ibidem, depositados no CIS; macho - Nova Teutônia, sem data, F. Plaumann, CIS; 8 fêmeas - Itapiranga, II/1953, MA. Rio Grande do Sul: 25 fêmeas e 9 machos - Porto Alegre, V/1953, Buckup, MCN 1996, 2025, 2061, 2052, 1992, 2070, 2012, 1998, 2004, 2003, 2001, 2064, 2047, 2038, 2046, 1993, 2023, 2026, 2006, 2007, 2009, 2010, 1989, 2071, 2058, 1999, 2000, 2049, 2024, 2005, 2060, 2011, 1990, 1995.

ARGENTINA: Misiones: 4 machos e 5 fêmeas - XI/1950, J. C. Lutz Collection, 1961, NMNH; 8 machos e 4 fêmeas - Eldorado, 12/X/1964, A. Kovacs, AMNH; macho e 2 fêmeas - Eldorado, 15/X/1964, A. Kovacs, AMNH. Buenos Aires: fêmea - Tandil, 25/I/1951, J. C. Lutz Collection 1961, NMNH. Corrientes: fêmea - Santiago Alcorte, XI/1941, Berger, MLP.

PARAGUAI: 7 machos e 3 fêmeas - Caacupé, I/1945, Mis. Cient. Brasil, IOC; 2 machos e 2 fêmeas - Vila Rica, P. Jörgensen, Coll. Jensen-Haarup, ZM; fêmea - Riacho del Oro, W. Sörensen, ZM.

Observações: Na descrição original de $D$. binotata Ruckes mencionou quatro parátipos, duas fêmeas e dois machos. No material remetido pelo AMNH só constaram dois parátipos, sendo um macho e uma fêmea.

Diagnose diferencial: $D$. corrosus se separa facilmente das demais espécies pela sua forma largamente ovalada e pelo padrão de distribuição das pontuações ferrugíneas do pronoto, escutelo e cório.

Dinocoris (Dinocoris) antennatus (Dallas, 1851)

(Figs. 5, 18, 31, 41, 57, 74, 91)

Stoll, 1788: fig. 290.

Dinidor antennatus Dallas, 1851: 166, partim (descr. orig. e macho do Pará); Walker, 1867: 199; 1868: 542.

Empicoris antennatus; Stal, 1872: 11; Lethierry \& Severin, 1893: 88; Kirkaldy, 1909: 220. 
Dinocoris robustus Ruckes, 1958: 147. Localidade tipo: Rio Tapiche. Peru. Syn. $n$.

Localidade tipo: Pará.

Tipo: Lectótipo macho aqui designado. Depositado no BM(NH). Dallas descreveu antennatus com base em um macho do "Para" e um casal de "S. America"; a descrição original se aproxima mais do macho do Pará, razão pela qual o designamos como lectótipo; o casal da América do Sul foi identificado como $D$. variolosus (Linnaeus).

Coloração geral ocre-alaranjada, com puncturações ferrugíneas no pronoto e calosidade basal do escutelo.

Antenas predominantemente ocre-alanrajadas com anéis negros no extremo apical do segundo artículo, cerca de metade ou mais do terceiro e nos dois terços apicais do quarto. A extensão do anel negro no terceiro artículo é variável.

Projeções triangulares do ápice das margens ântero-laterais do pronoto menos aguçadas que em $D$. variolosus. Peritrema ostiolar como em $D$. variolosus. Ápice do escutelo subtruncado, com pontuações isoladas nos três quartos apicais e confluentes ao nível da faixa transversal do disco do cório. Cório com pontuações ferrugíneas confluentes formando uma faixa transversal sobre o disco, que se continua sobre o escutelo. Outras concentrações de pontuações junto à base do cório e na distância média entre a base e a região discal.

Segmentos do conexivo com uma estreita faixa ferrugínea, junto às margens anterior e posterior, que se continuam na superfície ventral formando aí uma mancha ferrugínea em forma de cunha. Em alguns exemplares, presente uma linha longotudinal ferrugínea sobre a linha dos tricobótrios e uma pequena mancha ferrugínea sobre os espiráculos.

Pernas ocre-alaranjadas ou amarelo-sujo. Manchas escuras nas tíbias e fêmuras inconspícuas.

Macho: Comprimento total 15,38 (15,2 - 15,65); largura do pronoto $8 z 1$ $(7,6$ - 8,66); largura abdominal 9,95 (9,42 - 10,18).

Genitália do macho: Pigóforo e parâmeros muito semelhantes aos de $D$. variolosus diferindo principalmente nos seguintes aspectos: linha de "sutura" percorrendo a cápsula genital desde o bordo dorsal até a abertura basal; parâmero proporcionalmente mais volumoso, em vista dorsal "meia-lua" mais larga do que em $D$. variolosus (figs. 5 e 18). Phallus: Processo da vésica semelhante ao de $D$. variolosus, porém área com pregueamentos mais extensa; após o processo, curso da vésica em metade de um "S": gonóporo secundário voltado para o lado dorsal (figs. 31, 41 e 57 ).

Fêmea: Comprimento total 17,81 $(16,87$ - 18,54); largura do pronoto 9,84 $(9,12$ - 10,18); largura abdominal $11,4(10,33-12,00)$.

Genitália da fêmea: Placas genitais conforme ilustrado na figura 74 . Receptaculum seminis: capsula seminalis em forma de dedo, com diâmetro e comprimento duas vezes maior que a pars intermedialis; porção do ductus posterior à área vesicular com pregueamentos em sua metade distal, pouco mais curta que a porção do ductus anterior à área vesicular; região do receptaculum seminis posterior à área vesicular tão longa quanto esta; Chitinellipsen ausentes (fig. 91).

Material examinado: Lectótipo macho com as etiquetas: (a) Para/ 48133 (b) b (c) antennatus identified by Dallas. fêmea - sem dados, variolosus Hahn (nec Lin), 379/80, RS; fêmea - sem dados. Mus. Westerm. ZM.

BRASIL: macho e fêmea - Brasília bor [ealis], 383/80 e 386/80, RS. Amazonas: fêmea - PR Uhler coll., NMNH; fêmea - Amazon. sup. Olivença, 380/80 RS; fêmea - Benjamin Constant, X/1960, L. G. Pereira, DZPR; fêmea - Benjamin Constant, Rio Javari, VIII/1942, Dirings, MCN 2092; fêmea - Tefé, III/1959, Dirings, MCN; 6 fêmeas - Colônia de Borba, Borba, III/1943, A. Parko, CAS; fêmea - Colônia de Borba, Borba, III/1943, A. Parko, MCN 2089; 2 fêmeas -- Colônia de Borba, Borba, Pahl., AMNH; macho e fêmea - São Gabriel, Rio Negro, 30/IX e 3/X/1927, J. F. Zikán, 
IOC; fêmea - Igarapé Assu, 1912, J. R. de la Torre Bueno Collection, K. U., SEM. Pará: fêmea - 25/II/1874, Traull, AMNH; macho — Belém, IX/1935, DZRS. Espírito Santo: macho - Parque Sooretama, Linhares, III/1953, P. A. Teles, MCN 2093.

PERU: Loreto: fêmea - Rio Ucayali, IX/1929, F6116, H. Bassler Collection Acc. 33591, Dinocoris maximus Ruckes PARATYPE, AMNH; 5 fêmeas - Rio Tapiche, III/1928, F6154, H. Bassler Collection Acc. 33591, Dinocoris maximus Ruckes, PARATYPE, Dinocoris antennatus (Dall.) det. H. Ruckes, 1960 HOMOTYPE, AMNH. Junin: fêmea - San Ramon, 900 m, 5/i/1955, E. I. Schlinger \& E. S. Rosa, CAS. Cusco: fêmea - Quillabamba, 27/X/1963, F. Carrasco Z., DZRS.

BOLÍVIA: La Paz: 7 fêmeas - Caranavi, MLP.

Diagnose diferencial: A presença da faixa ferrugínea na região discal do cório, incluindo o escutelo, distingue $D$. antennatus de $D$. variolosus; esta espécie separa-se de $D$. histrio por apresentar as demais áreas do cório e escutelo cobertas por finas pontuações ferrugíneas.

Dinocoris (Dinocoris) gibbus (Dallas, 1852)

(Figs. 13, 26, 37, 47, 61, 75, 95)

Dinidor gibbus Dallas, 1852: 18, est. 1, fig. 7 .

Empicoris gibbus; Stal, 1872: 11; Lethierry \& Severin, 1893: 88; Kirkaldy, 1909: 220.

Dinocoris gibbus; Monte, 1945: 271; Becker \& Grazia-Vieira, 1971: 23.

Bryelica perigrinator (sic); Costa Lima, 1927: 78; 1936: 122; Monte, 1937: 71;

1939: 51; Bosq, 1940: 407 (nec Linnaeus, 1758).

Localidade tipo: Brasil.

Tipo: Originalmente na coleção particular de Mr. Dossetor; não se encontra no $\mathrm{BM}(\mathrm{NH})$, de acordo com as informações do Curador desta coleção.

Coloração geral amarelo-sujo ou castanha com pontuações negras formando seis linhas longitudinais no pronoto, quase no meio deste cortadas por linhas transversais; demais áreas com pontuações ferrugíneas.

Antenas quase totalmente negras, com anéis variáveis em extensão, de coloração ocre-alaranjado ou amarelado junto à base dos artículos; às vezes o segundo artículo parece dividido em dois, a região basal geralmente clara, com cerca de dois terços do comprimento total.

Margens ântero-laterais do pronoto fortemente sinuadas, formando uma curva sigmóide; ângulos umerais projetados em um nítido espinho dirigido para frente. Propleura, mesopleura e metapleura com pontuações negro-ferrugíneas. Área da metapleura, externa à área evaporatória, manchada de negro. Peritrema ostiolar elevado, ocupando quase a metade da margem anterior da área evaporatória metapleural. Escutelo com calosidade basal bem desenvolvida além de um pequeno calo central no início da região pós-frenal; ápice subtruncado, refletido de cada lado da linha média longitudinal; pontuações negras em toda a superfície do escutelo, mais concentradas na base, contornando os calos amarelados adjacentes aos ângulos basais. Cório totalmente coberto por pontuações ferrugíneas, confluentes em algumas áreas.

Conexivo com pontuações que se continuam na superfície ventral além das faixas ferrugíneas, anterior e posterior, de cada segmento. Margens laterais, na superfície ventral, nitidamente pontuadas; presente a faixa longitudinal ferrugínea que acompanha a linha dos tricobótrios.

Pernas totalmente pontuadas de ferrugíneo, destacando-se anéis no ápice das tíbias e próximo ao ápice dos fêmures. Tarso com o primeiro artículo e mais da metade do terceiro de coloração negra.

Macho: Comprimento total 12,16 (11,24 - 13,37); largura do pronoto 7,29 $(6,53$ - 7,9); largura abdominal 7,47 (6,68 - 8,2).

Genitália do macho: Bordo dorsal do pigóforo não expandido por sobre o $\mathrm{X}$ segmento, amplamente fendido na linha mediana, resultando um recorte 
em "V" de bordos espessos de cujo ápice segue uma linha de "sutura" que atinge a abertura basal do pigóforo. Projeções dorso-laterais curtas, na base semi-destacadas do corpo do pigóforo, espessas no bordo distal, este evanescente em direção à margem ventral do pigóforo. Parede ventral do pigóforo não elevada, margem vetral bi-sinuada, X segmento e parâmeros amplamente visíveis em vista ventral. Quando o pigóforo é observado em vista posterior, os parâmeros apresentam um aspecto peculiar, lembrando uma "chave-deboca" em que a reentrância em pronunciada meia-lua se situa em posição lateral (figs. 13 e 26). Phallus: Phallotheca mais inflada no lado ventral do que nas demais espécies do subgênero. Processo da vésica desprovido de pregueamentos, em colher que se inicia no lado ventral e se projeta livremente do lado dorsal, do centro da qual segue a vésica em curto tubo aberto em direção posterior (figs. 37, 47 e 61).

Fêmea: Comprimento total 13,83 (12,92 - 14,74); largura do pronoto 8,32 $(7,6$ - 9,27); largura abdominal 8,84 (8,36 - 9,27).

Genitália da fêmea: Bordos suturais dos gonocoxitos 8 divergentes em seus dois terços distais, expondo claramente o ápice do triangulum (fig. 75). Receptaculum seminis: Capsula seminalis em globo, desprovida de dentes ou com um ou mais dentes de tamanho variado; para intermedialis pouco mais longa que a capsula seminalis; região do ductus posterior à área vesicular com diâmetro maior do que na porção anterior à área vesicular e correspondendo a menos de um terço do comprimento desta; Chitinellipsen presentes (fig. 95).

Material examinado: VENEZUELA: Jusepin: fêmea - Monagas, 6/VIII/ 1966, F. Fernandez Y. \& C. J. Rosales, IZA; macho - Monagas, 2/VI/1967, J. Salcedo \& L. Rodrigues V., IZA.

BRASIL: Rondônia: fêmea - Acre, I/1957, Pe. Edison, MCN 2079. Goiás: macho e fêmea - Aragarças, XI/1965, Alvarenga, MZSP. Minas Gerais: macho e fêmea - Ibiá, 28/X/1965, C. Elias, DZPR; macho e fêmea - Belo Horizonte, O. Monte, MCN 1988; 2 fêmeas - Passos, 12-17/XI/1962, C. Elias, DZPR; macho e fêmea - Poços de Caldas, 23/XI/1962, C. Elias, DZPR; macho e fêmea - Poços de Caldas, I/1933, O. F., IB. Mato Grosso do Sul: fêmea - Salobra (Zona da Estrada de Ferro Noroeste do Brasil), 1829/X:1938, Inst. Oswaldo Cruz, IOC. São Paulo: 3 fêmeas - Angatuba, I/1922, A. Marques, MN; macho - Pirassununga, 28/X/1945, Schubart, MZSP; fêmea - Barueri, 20/X/1954, K. Lenko, MZSP; macho - Salto, 17/X/1976, G. Merliz, ZUEC 973; fêmea - Sorocaba, 30/X/1975, R. Braz, ZUEC 970; fêmea - Campinas, 17/XII/1972, ZUEC 972; fêmea - Campinas, 14/V/1976, M. A. Serna, ZUEC 971; fêmea - Campinas, 17/IX/1975, R. Braz, ZUEC 969; macho - Campinas, C. de Rezende, MN; fêmea George Oeterer, 22/XI/1961, Werner, MZSP; macho - São Paulo, MCN 2057. Paraná: 3 machos - Foz do Iguaçu, 7/XII/1966, D. Zoo U.F.P., armadilha de luz, DZPR. Santa Catarina: 3 machos e 12 fêmeas - Nova Teutônia, 31/X/1952, F. Plaumann, NMNH; macho e 5 fêmeas - Nova Teutônia, 7/XI/1952, F. Plaumann, NMNH; 2 machos e fêmea - Nova Teutônia, 27011'S 52²3'L, XI/1952, F. Plaumann, AMNH; macho e fêmea Corupá (Hansa Humboldt), XI/1945, A. Maller F. Johnson Donor, AMNH. Rio Grande do Sul: 31 fêmeas e 3 machos - Porto Alegre, V/1953, Buckup, MCN 2044, 2034, 2063, 2033，2017，2002，2045，2028, 2074, 2035, 2037, 2039, 2049, 2015, 2051, 2048, 2016, 2055, 2056, 2030, 2050, 2031, 2032, 2027, 2029, 2069, 2042, 2067, 2022, 2021, 2020, 2019, 2036, 2041; macho e fêmea - Porto Alegre, XII/1957, Buckup, MCN 2053, 2054; fêmea Porto Alegre, 13/IV/1962, C. Araujo; fêmea - 29/III/1961, C. Araujo; 3 fêmeas e 2 machos - Porto Alegre, 28/XI e 8-9/XII/1964, T. de Lema; 3 fêmeas - 19/XI/1967, T. de Lema; fêmea e macho - Porto Alegre, 15 e 21/XI/1964, J. Grazia; 2 fêmeas - Porto Alegre, 26/V/1955, R. E. B.; macho e fêmea - 16/XI/1967, G. Benvegnu; fêmea - Porto Alegrẹe, 22/XII/1951, MA; macho - Porto Alegre, I/1955, Camargo, MCN 2066; macho - Porto Alegre, 12/XII/1967, M. C. de Lema; macho - Porto Alegre, 22/XI/1967, M. Becker; 2 fêmeas - Porto Alegre, 13/VI/198-, D. Zancan. 
PARAGUAI: fêmea - Itapuá Vega, XII/1944, AMNH.

ARGENTINA: Jujuy: macho - Ledesma, 7/II/1928, H. E. Box, MLP.

Diagnose diferencial: Reconhece-se facilmente $D$. gibbus pela estrutura do pronoto com os ângulos umerais dotados de um nítido espinho projetado em direção anterior.

Dinocoris (Dinocoris) ramosus (Walker, 1868)

(Figs. 11, 24, 39, 49, 63, 76, 94)

Bryelica ramosa Walker, 1868: 547; Kirkaldy, 1909: 221.

Empicoris (Bryelica) ramosus; Stal, 1872: 11; Lethierry \& Severin, 1983: 89.

Empicoris ramosa; Distant, 1880: 49; 1889: 326.

Localidade tipo: “Oajaca” (México).

Tipo: Lectótipo macho aqui designado. Depositado no BM(NH).

Coloração geral ocre-avermelhado sujo.

Antenas com cinco artículos, em alguns exemplares o segundo e o terceiro são fusionados como em $D$. gibbus. O primeiro e o segundo artículos de coloração ocre ou castanha com pontuações ferrugíneas; terceiro totalmente escuro exceto, às vezes, um anel junto às articulações basal e apical de coloração ocre; quarto e quinto com o terço basal ocre.

Estrutura do pronoto como em $D$. corrosus porém com coloração bem distinta. Metade anterior com pontuações pouco mais escuras que a coloração geral do pronoto; cicatrizes marginadas por pontuações ferrugíneas; às vezes, junto à margem posterior das cicatrizes, uma linha calosa destituída de pontuações. Metade posterior do pronoto com pontuações negro-ferrugíneas mais grosseiras e, às vezes, algumas puncturações formando quatro faixas longitudinais: duas centrais, estando uma de cada lado do disco e duas externas, mais estreitas, situadas entre o disco e os úmeros. Ainda, sobre os úmeros as pontuações ferrugíneas formam uma faixa transversal estreita. Peritrema ostiolar em lâmina desenvolvida que ocupa mais da metade da margem anterior da área evaporatória metapleural. Calosidade da base do escutelo menos convexa que em $D$. corrosus, continuada por uma linha calosa longitudinal que percorre o terço médio do escutelo; ápice sub-arredondado, com uma meia-lua negro-ferrugínea. Pontuações negro-ferrugíneas marginam a calosidade basal do escutelo, sendo mais nítidas nas áreas laterais; outras pontuações de coloração ocre-ferrugínea ou apenas pouco mais escuras que a coloração geral do escutelo estão presentes. Cório com pontuações menores, ferrugíneas ou ocre-ferrugíneas ocasionalmente formando pequenas concentrações no ápice da veia radial.

Conexivo com pontuações ocre-ferrugíneas não formando faixas, às vezes, apenas uma cunha junto à margem lateral externa de cada segmento. Superfície ventral do abdome com pontuações grosseiras ocre-ferrugíneas, exceto sobre o disco; linha contínua de pontuações mais escuras sobre a linha dos tricobótrios que se apresentam como em $D$. nigroantennatus.

Pernas com pontuações castanhas, às vezes também presentes as manchas anelares das tíbias; tarsos mais escuros.

Macho: Comprimento total 11,09 (10,48 - 11,7); largura do pronoto 5,62 (5,01 - 5,92); largura abdominal 6,73 (6,23 - 7,29).

Genitália do macho: Projeções dorso-laterais do pigóforo laminares, em longas e lisas abas virtualmente não divergentes entre si, destacadas na base do corpo do pigóforo. Bordo dorsal do pigóforo projetado por sobre o $\mathrm{X}$ segmento, formando na frente deste uma linha côncava. Projeções ventrolaterais do pigóforo agudas, tão longas quanto as projeções do bordo dorsal; em vista lateral, profundo hiato entre elas. Parâmero, quando observado no pigóforo em vista dorsal, apresenta-se como uma longa haste percorrida no lado interno por uma alta carena ondulada; truncado no ápice e terminando em ponta aguda voltada para o exterior. Quando observado no pigóforo em vista posterior, esta carena ondulada, juntamente com outra, percurrente e 
Revta bras. Zool.

denticulada, limitam outra face alongada do parâmero, também truncada no ápice e projetada em ponta em direção às expansões ventro-laterais do pigóforo. No conjunto, as duas carenas e as duas projeções pontiagudas terminais conferem ao ápice do parâmero uma condição bífida, em "V" (figs. 11 e 24). Phallus: Phallotheca fortemente inflada em seu terço distal no lado dorsal, área inflada partindo de forma abrupta junto à abertura distal da phallotheca. Processo da vésica em bico chato, pronunciado, paralelo à plataforma da projeção da phallotheca. Curso da porção tubular da phallotheca em metade de "S"; gonóporo secundário voltado" para o lado dorsal (figs. 39, 49 e 63).

Fêmea: Comprimento total $13,74(12,92$ - 15,04); largura do pronoto 6,99 6,53 - 8,05); largura abdominal 8,54 (8,05 - 9,57).

Genitália da fêmea: Placas genitais conforme ilustrado na figura 76 . Receptaculum seminis: Capsula seminalis globosa, com dois dentes; pars intermedialis tão longa quanto ela; porção do ductus posterir à área vesicular quase dois terços tão longa quanto a porção do ductus anterior à área vesicular (fig. 94).

Material examinado: Lectótipo macho com as etiquetas: (a) Type (b) $58^{\circ} 135$ Mex. (Oajaca) (c) 1. Bryelica ramosa (d) BRIT. MUS. TYPE No. HEM. 685; Paralectótipo sem abdome com as etiquetas: (a) $58^{\circ} 135 \mathrm{Mex}$. (Oajaca) (b) Bryelica ramosa Walker's Catal.

MÉXICO: fêmea: et. by E. P. Van Duzec, SEM; 2 fêmeas - J. R. de la Torre Bueno Collection K. U.; macho - Matamoros, E. D. Ball, AMNH; Vera Cruz: fêmea - V. C. Cordoba, 29/VII/1965, A. B. Lau, NMNH; Nayarit: fêmea - $15 \mathrm{mi}$. N. Tépic, 25/VII/1954, M. Cazier W. Gertsch Badts Bryelica ramosa Walk. HOMOTYPE compared by Ruckes), AMNH; 3 fêmeas - mesmos dados do homótipo. Jalisco: fêmea - 0.2 mi. from Nayarit st. line, hwy nr. 15, 11/VIII/1963, Byers, SEM leg.; fêmea - 16,6 mi. W Guadalajara, 11/VIII/1963, G. W. Byers \& party, SEM leg.; Morelos: macho: - Morelos, $136 \mathrm{~km}$. South Mexico City, 14/VII/1936, H. D. Thomas, SEM; 2 fêmeas - Cuernavaca, VI/1898, E. D. Ball, AMNH; macho Cuernavaca, VI/1897, E. D. Ball, AMNH; macho - Cuernavaca, 14/V/1898, J. R. de la Torre Bueno, Collection K. U., SEM; macho - Cuernavaca, IV/1946, J. \& D. Pallister, AMNH. Oaxaca: fêmea - Temascal, 16-23/ VIII/1965, A. B. Lau, NMNH.

Diagnose diferencial: Esta espécie distingue-se facilmente das demais espécies por apresentar cinco artículos antenais.

Dinocoris (Dinocoris) gibbosus (Fallou, 1889)

(Figs. 10, 23, 36, 46, 62, 82, 85)

Brochymena gibbosa Fallou, 1889: 120.

Empicoris gibbosus; Bergroth, 1892: 263; Kirkaldy, 1909: 220.

Localidade tipo: "Minas Geraes", [Brasil], citada na descrição original.

Holótipo: Não foi localizado no Museu de Paris, embora conste uma etiqueta com o nome desta espécie na caixa número 12, coleção Fallou.

Coloração geral ocre-amarelado com puncturações ferrugíneas no pronoto e calosidade basal do escutelo, com numerosas áreas subcalosas, brilhantes, nos dois terços posteriores do pronoto.

Antenas com o primeiro artículo ocre-amarelado, com pontuações ou máculas ferrugíneas; segundo artículo, na metade basal inicialmente esfumaçado e a seguir ocre-amarelado, a metade posterior negra; terceiro e quarto artículos com um anel basal amarelo, o restante negro.

Margens ântero-laterais do pronoto com um pequeno espinho ou uma projeção triangular adjacente aos ângulos umerais. Peritrema ostiolar como em $D$. variolosus. Ápice do escutelo subarredondado, elevado de cada lado da linha média longitudinal, não tão refletido como em $D$. gibbus; pontuações ferrugíneas distribuídas pelos três quartos apicais do escutelo. Cório também coberto por pontuações ferrugíneas, menores que as do escutelo, na maioria não formando concentrações e nunca formando faixas transversais. 
Conexivo com pontuações ferrugíneas concentradas, às vezes formando faixas junto às margens anterior e posterior de cada segmento; estas faixas ocasionalmente se estendem para a superfície ventral. Linhas de pontuações interrompidas, ocasionalmente presentes sobre a linha dos tricobótrios na superfície ventral do abdome; pequenas manchas ferrugíneas sobre os espiráculos, às vezes presentes.

Patas ocre-amareladas com manchas ferrugíneas formando anéis, ora incompletos, nas tíbias quase junto à base e no ápice; nos fêmures também presente uma mancha ferrugínea mais próxima do ápice. A metade apical, ou mais, do terceiro artículo tarsal é negra, em especial nas pernas I e II, às vezes na III. Em alguns exemplares o primeiro artículo do tarso é também negro.

Macho: Comprimento total $12,37(12,00-13,68)$; largura do pronoto 7,02 $(6,38-7,6)$; largura abdominal 7,66 (6,99 - 8,36).

Genitália do macho: Bordo dorsal do pigóforo projetado por sobre o $\mathrm{X}$ segmento em largo anel interrompido no meio. Projeções dorso-laterais laminares, não divergentes entre si, superfície lisa, na base parcialmente destacadas no corpo do pigóforo, entre elas e a porção expandida por sobre o $\mathrm{X}$ segmento apenas um estreito hiato. Projeçốes ventro-laterais do pigóforo pontiagudas, finas; em vista lateral, profundo e estreito hiato entre elas e as projeções do lado dorsal, ápice de ambas atingindo o mesmo nível. Quando o pigóforo é observado em vista dorsal, parâmeros só parcialmente visíveis, encobertos pelas projeções dorso-laterais. Parâmeros alongados, percorridos por três carenas de tal forma que, em corte transversal, apresentam secção triangular; ápice do parâmero truncado (figs. 10 e 23). Phallus: Phallotheca dilatada de cada lado no terço mediano, afilando-se em direção às extremidades. Vésica com seu processo projetado para o lado dorsal, lembrando um bico de pato, depois seguindo em curso quase retilíneo, apenas no ápice voltada para o lado dorsal (figs. 36, 46 e 62).

Fêmea: Comprimento total 14,74 (14,28 - 15,5); largura do pronoto 8,05 $(7,75$ - 8,51); largura abdominal 8,93 (8,51 - 9,42).

Genitália da fêmea - Margem posterior do sétimo segmento abdominal muito fracamente sinuada, quase em linha reta (fig. 82). Receptaculum seminis: Pars intermedialis duas vezes mais longa que a capsula seminalis, dilatada em sua metade anterior e aí com diâmetro igual ao da capsula seminalis; porção do ductus posterior à área vesicular contorcida em sua metade posterior, comprimento correspondendo a dois terços da porção do ductus anterior à área vesicular. Chitinellipsen presentes (fُig. 85).

Material examinado: PANAMÁ: Canal Zone: macho - Barro Colorado Island, 25/IV/1962, H. Ruckes, Coll on NSF Grant G9830, NMNH; macho - Barro Colorado Isl., 10-17/V/1964, WD \& SS Duckworth, NMNH.

VENEZUELA: Aragua: fêmea - Camburito, 10/X/1945, FPR \& RL, em "algodón", IZA; fêmea - Gonzalito, 27/VI/1945, G. Budowsky, em "ajonjoli"; fêmea - El Limon, 450 m, 5/V/1961, F. F. Y.; 5 fêmeas - El Limon, 14/IX/1966, F. Fernandes Y. \& J. Semidey, em "ilang-ilang", IZA. Monagas: macho - Jusepin, 13/IX/1965, F. Fernandez Y. \& C. J. Rosales, IZA; macho - Jusepin, 11/X/1965, F. Fernandez Y. \& C. J. Rosales. Guarico: macho - Mesa de Paya, 12/V/1955, J. Loggiodice, IZA.

BRASIL: Amazonas: fêmea - Usina Hidroelétrica de Balbina, Presidente Figueiredo, 28-29/XII/1981, J. Grazia, DZRS; macho - Manaus, margem esquerda do Rio Negro, 6/VII/1941, Parko, mato e capoeiras "Alexo", IOC. Pará: macho e fêmea - Bragantina, II/1978, Garcia, em cacau, DZRS; fêmea - Rio Cuminá, 4/X/1936, Almeida, IOC. Pernambuco: macho - sem dados, DZRS. Minas Gerais: fêmea - Lagoa Santa, Reinhardt, ZM. Rio de Janeiro: fêmea - Usina Tijuca, Rio de Janeiro, 7/XI/1962, P. Bühnrheim, à luz, IOC; 3 machos - Itatiaia, IX/1929, Col. Dario Mendes, MN; fêmea Itatiaia, $816 \mathrm{~m}, 4 / \mathrm{XI} / 1928$, J. F. Zikán, IOC; fêmea - Jussaral, Angra [os Reis], XI/1934, Travassos, IOC. São Paulo: fêmea - Guarujá, X/1913, H. Luederwaldt, MZSP. Santa Catarina: fêmea - Joinville, Dirings 623, MCN 2099. 
Diagnose diferencial: D. gibbosus é muito próxima a $D$. rufitarsus da qual se distingue pela coloração dos tarsos.

Dinocoris (Dinocoris) rufitarsus Ruckes, 1958

(Figs. 9, 22, 35, 45, 60, 80, 93)

Dinocoris rufitarsus Ruckes, 1958:4. original.

Localidade tipo: Gatun Lake, Canal Zone, Panamá, citado na descrição

Holótipo: macho, depositado no AMNH.

Muito semelhante à $D$. gibbosus quanto à coloração das superfícies dorsal e ventral, antenas e distribuição das pontuações e puncturações. Diferencia-se por apresentar os tarsos avermelhados; os anteriores e médios apresentam o terceiro artículo enegrecido em pouco menos da metade apical. Em geral, as projeções no ápice das margens ântero-laterais do pronoto são pouco menores do que em D. gibbosus. Ápice do escutelo plano.

Macho: Comprimento total 12,88 (12,46 - 13,22); largura do pronoto $7,17(6.84-7,6)$; largura abdominal 7,9 (7,6 - 8,2).

Genitália do macho: Bordo dorsal do pigóforo moderadamente expandido por sobre o X segmento, deixando um largo "V" sobre a linha mediana. Projeções dorso-laterais laminares, com um dente ou pequena projeção triangular na altura mediana na margem voltada para o X segmento; na base, com indícios de constrição. Em vista lateral, projeções ventro-laterais ao mesmo nível que as dorso-laterais, entre elas hiato fundo, em "V" estreito. Quando o pigóforo é observado em vista posterior, os parâmetros são laminares, quase lanceolados; margem do lado ventral levemente ondulada pela presença de uma carena, margem do lado dorsal também percorrida por uma carena, que se projeta a meio caminho em dois dentes, entre eles resultando um raso recorte em "meia-lua"; ápice do parâmero dobrado por sobre o hiato entre as projeções do pigóforo (figs. 9 e 22). Phallus: Processo da vésica em colarinho justo junto à abertura da phallotheca, expandido no lado dorsal em lábio com pregueamentos, recurvado em direção ao gonóporo secundário. Vésica, após o processo, em tubo levemente recurvo para o lado dorsal, longo em relação ao das demais espécies do gênero, correspondendo a quase dois terços do comprimento da phallotheca (figs. 35, 45 e 60).

Fêmea: Comprimento total $15.35(14,89-15,8)$; largura do pronoto 8,39 $(8,2$ - 8,81); largura abdominal 9,57 (9,42 - 9,72).

Genitália da fêmea: Margem posterior do sétimo segmento abdominal muito rasamente sinuada nos terços laterais, fortemente côncava no terço mediano junto aos gonocoxitos 8 (fig. 80). Receptaculum seminis: Capsula seminalis duas vezes mais longa que a pars intermedialis; porção do ductus anterior à área vesicular pouco mais longa que a porção do ductus posterior à área vesicular; região do receptaculum seminis posterior à área vesicular quase tão longa quanto esta; Chitinellipsen presentes (fig. 93).

Material examinado: HONDURAS: macho e fêmea - Brus Lagoon, 25/IV/1947, C. W. Cook, Dinocoris rufitarsus Ruckes, PARATYPE, AMNH; 2 machos e 7 fêmeas - Brus Lagoon, 25/IV/1947, C. W. Cook, CAS.

NICARÁGUA: macho - sem dados, NMNH.

PANAMÁ: Canal Zone: macho e fêmea - B. [arro] C. [olorado] I. [sland], 23/V e 3/VI/1957, F. Schrader, Dinocoris rufitarsus Ruckes, PARATYPE, AMNH; 2 machos e fêmea - Barro Colorado, 25/IV e 1/VII/1962, H. Ruckes, NMNH; macho - Barro Colorado, 15/IV/1932, S. W. Frost, NMNH; 3 fêmeas e macho - Barro Colorado, 18-28/IV, 28-30/IV e 1-9/V/ 1964, WD \& SS Duckworth, NMNH; 2 fêmeas - Barro Colorado 10-20/IV/ 1965, WD \& SS Duckworth, NMNH; fêmea - Barro Colorado (Biol. Station), 5-8/VIII/1965, MZSP; 3 machos - Barro Colorado, 19 e 21/II/1955, C. Rettenmeyer, SEM; macho - Barro Colorado, 22/IX/1976, D. Engelman, armadilha de luz; fêmea - Ft. Clayton, IV/1944, K. E. Frick, Dinocoris 
rufitarsus Ruckes, PARATYPE, AMNH; macho - Pearl Island, San Jose, 27/VIII/1944, Morrison JPE, NMNH.

COLÔMBIA: Santader: fêmea - San Vicente, 692 m, VI/1935, L. M. Murillo, AMNH. Cundinamarca: fêmea - Bogotá, B. Guevara, NMNH. Valle del Cauca: macho e 2 fêmeas - Palmira, VII/1942, B. Losada S., AMNH; fêmea - Palmira, I/1944, B. Losada S., AMNH.

BRASIL: Amazonas: fêmea - Manaus, Estrada do Aleixo Km 4 (INPA), V/1973, A. Castrilon. Maranhão: fêmea - São Luís, 1/VIII/1976, E. Chagas, DZRS. Minas Gerais: fêmea - Monlevade, Ed. Luja, Brit. Mus. 1932-282, AMNH. Rio de Janeiro: fêmea - Corcovado, 15/IX/1961, J. S. Moure, Alvarenga \& Seabra, DZPR.

Diagnose diferencial: Pela coloração da superfície dorsal, D. rufitarsus e $D$. gibbosus se aproximam de $D$. variolosus por não apresentarem faixas transversais ferrugíneas no cório; distinguem-se de $D$. variolosus pela coloração da superfície ventral do abdome.

Observações: No material enviado pelo AMNH havia apenas cinco parátipos, três fêmeas e dois machos, embora na descrição original Ruckes mencionasse, além do holótipo macho e alótipo fêmea, mais onze parátipos, sendo cinco machos e seis fêmeas.

\section{Dinocoris (Dinocoris) reticulatus, sp. n.}

(Figs. 1, 7, 20, 33, 43, 58)

Localidade tipo: Lagoa Santa, Minas Gerais, Brasil.

Holótipo: macho, depositado no MZSP.

Coloração geral ocre-amarelado com pontuações negro-ferrugíneas ou ferrugíneas. Pronoto e base do escutelo não puncturados.

Jugas menos sinuadas que nas demais espécies e separadas diante do clípeo. Antenas como em D. gibbus, tendo o segundo e terceiro artículos fusionados.

Ângulos ântero-laterais do pronoto não desenvolvidos em pequenas projeções; ápice das margens ântero-laterais formando com os ângulos umerais um ângulo reto. Pontuações negro-ferrugíneas formando oito linhas longitudinais; as duas centrais iniciam na margem anterior, as seguintes iniciam na margem posterior das cicatrizes e as demais iniciam numa linha transversal que parte dos ângulos umerais e percorrem pouco mais do que o terço lateral do pronoto. Peritrema ostiolar elevado, bem desenvolvido, ocupando a metade da margem anterior da área evaporatória metapleural. Calosidade basal do escutelo pouco desenvolvida, como em $D$. ramosus; ápice uniformemente arredondado. Linhas longitudinais de pontuações ferrugíneas dispostas uma de cada lado da linha média longitudinal ocre-amarelada, mais ou menos em continuação às linhas centrais do pronoto. Outras linhas ferrugíneas menores adjacentes aos calos basais; demais áreas do escutelo com manchas subcalosas, lisas, ocre-amareladas, limitadas por linhas ferrugíneas que conferem um aspecto reticulado. Este padrão se repete no cório, porém formando retículos maiores. Ainda no cório, uma linha contínua de pontuaçóes negroferrugíneas acompanha a veia radial e estende-se quase até a sutura da membrana.

Segmentos do conexivo com uma faixa ferrugínea junto às margens anterior, posterior e lateral interna, com este padrão repetido na superfície ventral.

Pernas ocre-avermelhadas, com manchas ferrugíneas nas tíbias, uma apical e outra próximo à base e, nos fêmures, uma próxima ao ápice, além das pontuações nas áreas ocre-avermelhadas das tíbias. Tarsos com o artículo basal e metade do apical negro-ferrugíneos.

Macho: Comprimento da cabeça 1,82; largura da cabeça 2,28; comprimento diante dos olhos 1,06; distância interocular 1,21; comprimento dos artículos antenais I, 1,06 (os demais faltam); comprimento do pronoto 2,12; largura do pronoto 5,92; comprimento do escutelo 4,4; largura do escutelo 3,49; largura abdominal 6,68; comprimento total 11,9 . 
Genitália do macho: Projeções dorso-laterais do pigóforo ocupando uma posição mais dorsal no pigóforo do que nas demais espécies do subgênero; margem interna - voltada para o X segmento - e a margem distal, formando juntas um ângulo agudo (figs. 7 e 20) (A preparação para o exame do phallus precedeu a descrição dos parâmeros no local). Phallus: Processo da vésica como uma crista em meio colarinho na metade ventral, continuando-se na metade dorsal como uma projeção em forma de colher, com pregueamentos, a qual envolve a base de uma área protuberante. Curso da vésica, após o processo, em "V" aberto; gonóporo secundário voltado para o lado dorsal (figs. 33, 43 e 58).

Material examinado: Brasil: Minas Gerais: holótipo macho - Lagoa Santa, 28/I/1963, N. Papavero, depositado no MZSP.

Diagnose diferencial: Por não apresentar o pronoto e a base do escutelo puncturados e pelo ápice das margens ântero-laterais formando um ângulo reto com os ângulos umerais, esta espécie assemelha-se a $D$. ramosus e $D$. corrosus das quais se distingue facilmente pelo padrão de coloração reticulado do pronoto, escutelo e cório.

Dinocoris (Dinocoris) fabricii, sp. n.

(Figs. 12, 25, 38, 48, 65)

Localidade tipo: desconhecida.

Holótipo: macho, depositado no ZM.

Coloração geral ocre-amarelada, com puncturações ferrugíneas no pronoto e calosidade basal do escutelo. Duas faixas de pontuações ferrugíneas no pronoto, uma de cada lado da faixa mediana longitudinal, esta com menor número de puncturações e, portanto, um maior número de áreas subcalosas. Estas faixas do pronoto se continuam pela calosidade basal do escutelo.

Margens ântero-laterais do pronoto formando no ápice uma projeção triangular pouco maior que as projeções dos ângulos ântero-laterais. Escutelo, nos dois terços apicais, com pontuações ferrugíneas; ápice arredondado. Peritrema ostiolar elevado, ocupando apenas o quarto da margem anterior da área evaporatória metapleural. Cório com fina pontuação ferrugínea, distribuída irregularmente, porém não formando concentrações.

Conexivo com pontuações, além de inconspícuas faixas ferrugíneas nas margens anterior e posterior de cada segmento. De cada lado do abdome, na superfície ventral, uma larga faixa, interna à faixa marginal e sobre a linha dos espiráculos, de coloração ferrugínea.

Pernas com manchas inconspícuas nas tíbias e fêmures, provavelmente esmaecidas pela idade do exemplar.

Macho: Comprimento da cabeça 1,92; largura da cabeça 2,82; comprimento diante dos olhos 1,2 ; distância interocular 1,5; antenas faltam; comprimento do pronoto 2,2 ; largura do pronoto 6,84 ; comprimento do escutelo 5,82; largura do escutelo 4,2; largura abdominal 8,1; comprimento total 12,3 .

Genitália do macho: Bordo dorsal do pigóforo virtualmente não projetado por sobre o X segmento, a seguir com uma área escavada de cada lado à qual se segue a projeção dorso-lateral, digitiforme, com superfície irregular. Margem ventral do pigóforo em " $U$ " raso, projeções laterais pequenas. Em vista lateral, hiato entre as projeções dorso-laterais e dorso-ventrais pequeno em relação ao das demais espécies do grupo a que pertence no subgênero. Parâmero fugindo do padrão comum ao gênero, podendo ser considerado como constituído de "pé" e "cabeça"; esta, volumosa e fortemente esculturada (figs. 12 e 25). Phallus: Diâmetro distal da phallotheca grande em relação ao das demais espécies do gênero; abertura distal da phallotheca lateralmente com um par de pequenos processos de contorno arredondado. Vésica projetada dorso-posteriormente em processo amplo e liso, como um cotovelo dobrado, continuando-se em tubo curto e fino, fortemente dobrado para o lado ventral, de forma que o gonóporo secundário se abre em direção posterior (figs. 38, 48 e 65$)$. 
Material examinado: Holótipo macho, sem dados, ZM. (Este exemplar estava em uma caixa contendo exemplares da coleção original de Fabricius, com a etiqueta verde indicativa de tal, como sendo $H$. variolosa).

Diagnose diferencial: $D$. fabricii se distingue das demais espécies por apresentar duas largas faixas ferrugíneas longitudinais no pronoto.

\section{Dinocoris (Dinocoris) nigroantennatus, n. sp.}

(Figs. 77 e 96)

Coloração geral ocre-amarelada ou testácea, com densa puncturação ferrugínea no pronoto e calosidade basal do escutelo, e sobre eles, poucas áreas lisas, subcalosas e brilhantes.

Antenas quase totalmente negras, exceto uma faixa longitudinal interna no primeiro artículo, manchas na base do segundo artículo e um estreito anel na base do terceiro artículo, de coloração amarelada.

Ápice das margens ântero-laterais do pronoto com uma pequena projeção triangular, apenas pouco maior que as projeções dos ângulos ântero-laterais. Peritrema ostiolar como em D. variolosus. Ápice do escutelo sub-arredondado, com uma pequena mancha ferrugínea de cada lado da linha média longitudinal; demais pontuações, ferrugíneas, pequenas, irregularmente distribuídas, às vezes concentradas nos pontos onde o freno encontra o escutelo. Cório com pontuações ferrugíneas formando duas faixas transversais irregulares, uma junto à base e outra sobre o disco, além de pontuações isoladas, dispersas irregularmente sobre a superfície do cório.

Segmentos do conexivo com uma faixa ferrugínea anterior e outra posterior, esta continuando-se ventralmente; no centro de cada faixa escura anterior, às vezes presente uma pequena mancha testácea. $\mathrm{Na}$ superfície ventral e de cada lado do abdome, presente uma faixa longitudinal ferrugínea que se estende do segundo ao sétimo segmnto, acompanhando a linha dos tricobótrios, estes implantados sobre pequenas áreas subcalosas e amareladas; sobre os espiráculos uma mácula arredondada e ferrugínea.

Amplos anéis negro-ferrugíneos no terço basal e apical das tíbias, pontuações ferrugíneas isoladas entre estes anéis. Fêmures com manchas ferrugíneas mais próximas do ápice, na superfície dorsal e, ocasionalmente, pontuações escuras no terço médio.

Fêmea: Comprimento da cabeça 2,65 (2,55 - 2,74); largura da cabeça 2,65 (2,63 - 2,67); comprimento diante dos olhos 1,57; distância interocular 1,65; comprimento dos artículos antenais I, $1,88(1,76-2,0)$; II, 4,48; III, 3,52; IV, 3,12; comprimento do pronoto $3,16(3,12-3,2)$; largura do pronoto $7,36(7,28$ - 7,44); comprimento do escutelo $6,6(6,4-6,8)$; largura do escutelo 4,8; largura abdominal 8,36 8,32 - 8,4); comprimento total $13,6(13,22$ 13,98).

Genitália da fêmea: Margem posterior do sétimo segmento abdominal retilínea nos terços laterais, fortemente côncava no terço mediano adjacente aos gonocoxitos 8 (fig. 77). Receptaculum seminis: conjunto pars intermedialis e capsula seminalis bastante pequeno em relação às demais partes do receptaculum seminis; capsula seminalis como uma mera dilatação terminal; pars intermedialis correspondendo a aproximadamente um quarto do comprimento da porção do ductus posterior à área vesicular; esta porção do ductus em tubo fino, correspondendo a pouco mais da metade do comprimento da porção do ductus anterior à área vesicular; Chitinellipsen presentes (fig. 96).

Material examinado: Colômbia: holótipo fêmea — Guayabetal, 10/V/1946, AMNH.

Parátipos: COLÔMBIA: Cundinamarca: fêmea - Bogotá, Lindig, 385/ 80 , RS.

PERU: fêmea - Achinamiza, 2/I/1926, H. Bassler Coll. Acc. 33 591, AMNH (Homotype, Dinocoris antennatus (Dall.) H. Ruckes det.).

Diagnose diferencial: pelas antenas quase totalmente negras e por apresentar faixas transversais de pontuações ferrugíneas apenas no cório, não continuadas pelo escutelo, distingue-se de D. antennatus e D. histrio. 
Subgênero Praedinocoris, subg. n.

Forma geral do corpo oval alongada ou semielíptica, mais ou menos deprimido dorso-ventralmente. Superfícies dorsal e ventral cobertas por pontuações concolores ou ferrugíneas, estas últimas distribuídas de maneira a formar linhas longitudinais e ocasionalmente manchas, dispostas de maneira característica em cada uma das espécies.

Comprimento da cabeça diante dos olhos maior do que a distância interocular. Margens laterais da cabeça quase retas, imperceptivelmente sinuadas adiante dos olhos; jugas estendendo-se além do clípeo em cerca de um quinto de seu comprimento, correspondendo a uma proporção bem maior do que no subgênero Dinocoris. Antenas com quatro artículos; segundo com uma vez e meia, ou mais, o comprimento do terceiro; terceiro e quarto sub-iguais. Segundo artículo totalmente negro.

Margem anterior do pronoto emarginada ou não; margens ântero-laterais sinuadas no meio, emarginadas; ângulos umerais em ângulo reto. Pontuações concolores e ferrugíneas delicadas, cobrindo a superfície do pronoto, estas últ:mas distribuídas em linhas longitudinais. Cicatrizes mais ou menos aplainadas, com pontuações ferrugíneas no disco ou túmidas e destituídas de pontuações. Mesosterno com uma estreita carena longitudinal, em continuação à carena do metasterno, exceto em $D$. prolineatus onde a carena se torna pouco conspícua no terço médio do mesosterno. Metasterno em hexágono de lados iguais de tal forma que a distância entre as mesocoxas é igual à distância de uma mesocoxa à metaxoca correspondente. Área evaporatória metapleural estendendo-se pelos do's terços internos da largura do segmento; peritrema ostiolar em lâmina elevada que ocupa a metade ou pouco menos da largura da margem anterior da área evaporatória. A calosidade da base do escutelo está ausente; apenas o triângulo basal e a linha média longitudinal são pouco mais elevados. Também os calos adjacentes aos ângulos basais do escutelo estão ausentes. Ápice do escutelo arredondado ou de contorno triangular, não emarginado.

Conexivo moderadamente exposto. Cório praticamente alcançando os ângulos póstero-laterais do sétimo segmento do conexivo, em especial nos machos. Membrana ultrapassando em muito o ápice do abdome (exceto em D. prlineatus), esfumaçada, com veias claras formando retículos ou não, entre elas manchas lineares escuras.

Genitália do macho: Pigóforo em taça rasa e muito aberta, bordo dorsal expandido de cada lado em projeções divergentes entre si que se afilam para o ápice, com base larga e perfeitamente destacada do corpo do pigóforo, bem mais longas do que o comprimento deste sobre a linha mediana, entre o bordo dorsal e a abertura basal. Bordo dorsal não expandido por sobre o $\mathrm{X}$ segmento, porém com uma protuberância junto à base de cada projeção dorso-lateral. X segmento com parede dorsal elevada, terminando em um par de tubérculos; restante em tubo simples. Parede ventral do pigóforo com sua margem se elevando em linhas convergentes a partir da base das projeções dorso-laterais, formando em seu terço mediano um par de projeções laminares, triangulares, de obtusas a pontiagudas, de um lado e outro do $\mathrm{X}$ segmento, resultando entre elas um forte recorte em "V". Quando o pigóforo é observado em posição dorsal, o par de projeções da margem ventral é visível entre o $\mathrm{X}$ segmento e o par de projeções dorso-laterais do pigóforo. Parâmeros não atingindo o ápice das projeções dorso-laterais, divergentes entre si no mesmo grau que estas, losangulares quando o pigóforo é observado em vista posterior. Phallus: Phallotheca inflada no lado ventral, por sobre sua abertura distal. Vésica desprovida de processo, em simples tubo pouco sinuoso.

Genitália da fêmea: Conforme descrito para o gênero.

Espécie tipo: Dinocoris (Praedinocoris) lineatus (Dallas, 1852). 
Dinocoris (Praedinocoris) lineatus (Dallas, 1852)

(Figs. 14, 27, 54, 55, 68, 69, 70, 79, 86)

Dinidor lineatus Dallas, 1852: 11, est. 1, fig. 4.

Dinidor strigatus Walker, 1868: 542. Localidade tipo: “Amazon Region”.

Empicoris lineatus; Stal, 1872: 10; Lethierry \& Severin, 1893: 88.

Empicoris strigatus; Kirkaldy, 1909: 220.

Empicoris hiulcus Bergroth, 1891: 221. Localidade tipo: "Brasilia: Minas

Geraes". Lethierry \& Severin, 1893: 88; Kirkaldy, 1909: 220.

Dinocoris lineatus; Becker \& Grazia-Vieira, 1971: 23; Grazia (no prelo).

Localidade tipo: Pará [Brasil], citada na descrição original.

Tipo: holótipo, único exemplar. Depositado no $\mathrm{BM}(\mathrm{NH})$.

Coloração geral ocre-alaranjada ou amarelada. Na cabeça, estreitas faixas longitudinais ferrugíneas marginando o clípeo que se continuam por sobre os ocelos. No pronoto, quatro faixas longitudinais ferrugíneas: as internas seguem as linhas da cabeça e se prolongam sobre os ângulos basais do escutelo. $\mathrm{Na}$ base do escutelo, uma estreita linha ferrugínea no meio; dois terços apicais do escutelo com duas linhas ferrugíneas subparalelas. Nos hemiélitros, uma linha de pontuações ferrugíneas acompanha a veia radial. Membrana com veias não formando retículos.

Cabeça triangular, com as jugas afilando-se em direção ao ápice e aí formando uma ampla incisura em "V". Rostro quase alcançando a margem posterior do quarto urosternito. Antenas com o primeiro artículo negro, exceto uma faixa dorsal amarelada; terceiro e quarto artículos negros, com um anel amarelado no terço basal.

Margem anterior do pronoto não emarginada; cicatrizes mais ou menos aplainadas com pontuações ferrugíneas no disco. Área evaporatória metapleural de coloração ocre com pontuações ferrugíneas, concentradas junto à sua margem externa; peritrema ostiolar não alcançando o meio da margem anterior da área evaporatória. Ápice do escutelo obtuso.

Segmentos do conexivo com manchas escuras junto às suas margens anterior e posterior. Superfície ventral ocre-amarelada com pontuações ferrugíneas mais densas nas pleuras. Externamente aos espiráculos ferrugíneos, uma faixa irregular de pontuações, mais ou menos confluentes, quase negras; nesta faixa escura destacam-se os tricobótrios, implantados sobre pequenas áreas circulares, subcalosas e amareladas.

Macho: Comprimento total 13,55 (11,55 - 14,89); largura do pronoto $6,2(5,16-6,84)$; largura abdominal 6,99 (6,08 - 7,6).

Genitália do macho: Tubérculos da parede dorsal do X segmento não divergentes entre si, resultando entre eles um estreito "V". Tubérculos do bordo dorsal do pigóforo voltados para fora. Quando o pigóforo é observado em vista dorsal, os parâmeros se apresentam em losango de margens côncavas, ápice pontiagudo, recurvo, na região apical com uma aba saliente, em lâmina de contorno triangular, voltado para as projeções laterais do pigóforo, ass:m como o próprio ápice do parâmetro (figs. 14 e 27). Phallus: Limite phallotheca-vésica inexistente; vésica em tubo muito curto (figs. 54, 55 e 68).

Fêmea: Comprimento total 15,56 (14,89 - 16,56); largura do pronoto $6,99(6,68$ - 7,6); largura abdominal 8,26 (7,75 - 8,66).

Genitália da fêmea: Placas genitais conforme ilustrado nas figuras 69 e 79. Receptaculum seminis: Capsula seminalis simples, globosa, ou com dentes simples ou bífidos; em qualquer caso, a pars intermedialis é mais longa que ela; porção do ductus posterior à área vesicular com um único e forte dobramento junto à crista anular anterior, afilada em direção à área vesicular do ductus; porção do ductus anterior à área vesicular quase duas vezes mais longa que a porção do ductus posterior à área vesicular; Chitinellipsen presentes (figs. 70 e 86 ).

Material examinado: Holótipo fêmea com as etiquetas: (a) Amaz (b) Type (c) 6612 (d) Dinidor strigatus (e) BRIT. MUS. TYPE No. HEM. 684.

VENEZUELA: Aragua: fêmea - El Castaño, Cr Maracay, 19/VI/1956, em "Almendron", F. Fernandez Y., IZA. 
GUIANA: macho - Bartica, H. S. Parish, J. R. de la Torre Bueno Collection K. U., SEM.

SURINAME: Marowijne: macho e 5 fêmes - Langaman Kondre, 20-21/ VIII/1965, B. Malkin, MZSP.

GUIANA FRANCESA: fêmea - 1899, R. Oberthür, COLL. BAR, MP.

BRASIL: macho - sem dados, Dinocoris lineatus (Dall.) det. H. Ruckes, 1960, MP. Amazonas: fêmea - Benjamin Constant, Rio Javari, Alto Amazonas, VIII/1942, Dirings, MCN 2078; fêmea - Uypiranga, Rio Negro, 14 $\mathrm{km}$ from Manaus, $81 \mathrm{~m}, 15 / \mathrm{XI}-15 / \mathrm{XII} / 1941$, A. Rabaut, AMNH; macho Tarumã Mirim, Manaus, 16/VII/1976, DZRS. Ceará: fêmea - Messejana, 30/X/1967, F. Farias, SDSV, MN; fêmea - Fortaleza, 17/X/1967, R. Duarte, MN; fêmea - Fortaleza, sem data, F. Oliveira, FACE; macho e 2 fêmeas Fortaleza, 1/V, 1/VI e 13/X/1980, em castanhola, FACE; 3 fêmeas - Fortaleza, 5/IV, 17/IV e 17/V/1981, em castanhola, FACE; 2 fêmeas e macho - Fortaleza, 4/V, 11/VI e 15/X/1980, FACE; macho e fêmea - Fortaleza, 2/VI e 1/X/1981, FACE. Minas Gerais: fêmea - Belo Horizonte, 23/I/1963, Papavero, MZSP; macho - Pirapora, 11-13/XI/1919, Cornell Univ. Expedition, Lot. 569, AMNH. Goiás: 2 machos - Fazenda Nova Orlândia, Jataí, I/1964, Martins, Morgante \& Silva, MZSP. Rio de Janeiro: fêmea - Corcovado, Rio de Janeiro, X/1975, C. A. Campos Seabra, MN. São Paulo: fêmea - Limeira, XI/1931, D. F., MCN 2076. Rio Grande do Sul: macho - Marcelino Ramos, 20/I/1940, MCN 2075.

PERU: fêmea - Quiroz, sem data, F. Woytkowski, Dinocoris lineatus (Dallas) (HOMOTYPE, compared by Ruckes), AMNH.

Diagnose diferencial: $D$. lineatus se aproxima de $D$. prolineatus, distinguindo-se facilmente pela disposição das faixas ferrugíneas na superfície dorsal, em especial as quatro faixas longitudinais do pronoto que são contínuas e livres.

\section{Dinocoris (Praedinocoris) prolineatus, sp. n.}

(Figs. 2, 15, 28, 52, 53, 66, 81, 89)

Localidade tipo: Santa Maria, Rio Grande do Sul, Brasil.

Holótipo: macho, depositado no MN.

Muito semelhante a $D$. lineatus, diferenciando-se, especialmente, por apresentar além das quatro faixas longitudinais ferrugíneas no pronoto, uma estreita faixa ferrugínea que margina as cicatrizes, unindo transversalmente as faixas longitudinais. Ainda no escutelo, as linhas ferrugíneas que percorrem os dois terços apicais são inconspícuas, geralmente sinuosas e não subparalelas como em $D$. lineatus. Antenas: anéis amarelados do $4 .^{\circ}$ artículo, e as vezes do $3 .^{\circ}$, estendendo-se pela sua metade basal. Aparentemente as manchas escuras dos segmentos do conexivo são mais amplas.

Tamanho médio, menor do que em $D$. lineatus.

Cabeça: a incisura em "V" do ápice das jugas é menos evidente do que em $D$. lineatus; rostro quase atingindo a margem posterior do $3 .^{\circ}$ urosternito.

Ápice do escutelo arredondado.

Área evaporatória metapleural com amplas manchas negro-ferrugíneas; peritrema ostiolar atingindo o meio da margem anterior da área evaporatória.

Membrana do hemiélitro com veias formando retículos, caráter este que distingue $D$. prolineatus das demais espécies do subgênero Praedinocoris.

Macho: comprimento da cabeça 1,93 (1,82 - 1,97); largura da cabeça 2,38 (2,28 - 2,43); comprimento da cabeça diante dos olhos $1,29(1,21$ - 1,52); distância interocular $1,36(1,21$ - 1,52); comprimento dos artículos antenais I, $0,98(0,91-1,06) ;$ II, 3,29 (3,19 - 3,49); III, 2,21 (2,12 - 2,43); IV, 1,5; comprimento do pronoto $2,23(2,12$ - 2,43); largura do pronoto $5,7(5,47$. 5,92); comprimento do escutelo 4,33 (4,1 - 4,56); largura do escutelo 3,42 $(3,19-3,8)$; largura abdominal $6,49(6,23-6,84)$; comprimento total 11,73 $(11,24 \cdot 12,46)$. 
Gentália: Tubérculos da parede dorsal do X segmento divergentes, resultando uma linha em "V" muito aberto entre eles. Tubérculos do bordo dorsal do pigóforo voltados em direção posterior. Parâmero como em $D$. lineatus, porém a projeção laminar da região apical do parâmero é de contorno quase semicircular e se inicia no próprio ápice do parâmero (figs. $15 \mathrm{e}$ 28). Phallus: Vésica com vestígio de processo em sua base, na superfície ventral; porção tubular quase retilínea (figs. 52, 53 e 66).

Fêmea: Comprimento da cabeça 2,28 (2,12 - 2,46); largura da cabeça 2,61 (2,43 - 3,04); comprimento diante dos olhos 1,52 (1,36 - 1,67); distância interocular $1,39(1,36$ - 1,52); comprimento dos artículos antenais I, $(1,21$ $(1,06-1,52) ;$ II, 3,57 (3,19 - 3,95); III, 2,31 (2,12 - 2,58); IV, 2,2 $(1,97-2,43)$; comprimento do pronoto $2,58(2,43-2,88)$; largura do pronoto $6,35(5,92$ - 6,99); comprimento do escutelo 5,16 (4,71 - 6,08); largura do escutelo $3,95(3,64-4,56)$; largura abdominal 7,75 (7,44 - 8,2); comprimento total $13,55(12,61-15,35)$.

Genitália: Placas genitais conforme ilustrado na figura 81. Receptaculum seminis: capsula seminalis globóide, pouco mais curta que a pars intermedialis; região do ductus posterior à área vesicular sanfonada em sua metade distal, um terço mais curta que a região do ductus posterior à área vesicular. Chitinellipsen ausentes (fig. 89).

Material examinado: BRASIL: Rio Grande do Sul: holótipo macho Santa Maria, 23/IV/1973; L. E. M. Reis, MN.

Parátipos: BRASIL: Mato Grosso: macho - Corumbá de G. [Goiás], 4/II/1962, J. \& B. Bechyné, MG. Rio Grande do Sul: macho - Santa Maria, 13/V/1973, P. T. Vasconcelos, DZRS.

ARGENTINA: Entre Rios: fêmea - Concordia, sem data, Hayward, MLP; 8 fêmeas - Salto Chico, Concordia, 21/VII/1951, Nunez, MLP (3), MZSP (1), DZRS (1), MN (1), Ex-Coll. H. Ruckes/AMNH (2). Corrientes: fêmea - Santo Tomé, 12/XI/1957, Birabén, MLP; fêmea - sem data, MLP. Chaco: fêmea - Resistência, 21/XI/1938, MLP.

PARAGUAI: Guaira: fêmea - Vila Rica, 25/X/1951, J. C. Lutz Coll. 1961, NMNH.

URUGUAI: Paysandu: fêmea - Puerto Pepe Aji, 18-21/IV/1967, C. S. Morey, E. M. Casella, C. E. Casini, DZRS; macho - Puerto Pepe Aji, 18/I/1965, L. G. Carboned, M. A. Monné, DZRS.

Dinocoris (Praedinocoris) nigrodecoratus, sp. n. (Figs. 3, 16, 29, 50, 51, 67, 83, 90)

Localidade tipo: Taperinha, Santarém, Pará, Brasil.

Holótipo: fêmea, depositado no MZSP.

Coloração geral amarelo-marfim com pontuações concolores uniformemente distribuídas; manchas negras com distribuição peculiar na superfície dorsal. Pronoto: um par de pequenas manchas na margem anterior; manchas maiores, quadrangulares, sobre os úmeros; estreitas faixas longitudinais delimitando o terço médio do produto, que iniciam na base da cabeça, unidas por uma estreita faixa transversal sobre a margem posterior do pronoto. Escutelo: três manchas basais, as laterais correspondendo às linhas que cortam os ân gulos basais e a central, menor; na altura média do escutelo uma faixa negra central, divergente em direção posterior, ou duas linhas negras paralelas ou, ainda, duas manchas em " $V$ " de braços desiguais. Hemiélitros: exocório com uma pequena mancha triangular negra no limite do terço basal; endocório com uma mancha posterior em relação a do exocório, às vezes inconspícua; ápice da veia radial com uma mancha arredondada.

Cabeça: jugas subparalelas, arredondadas no ápice e sobrepostas sobre o clípeo. Antenas, com exceção do $1 .^{\circ}$ artículo, totalmente negras. Rostro atingindo o meio do $3 .^{\circ}$ urosternito.

Pronoto: margem anterior emarginada; cicatrizes túmidas, calosas, destuídas de pontuações no disco. 
Escutelo: ápice de contorno triangular.

Membrana do hemiélitro com veias longitudinais, não formando retículos.

Pleuras marginadas lateralmente de negro-ferrugíneo.

Conexivo: uma mancha triangular ou retangular junto à base e uma estreita linha junto ao ápice dos segmentos, sendo que a primeira se continua na superfície ventral, alcançando os espiráculos negro-ferrugíneos e, às vezes, projetando-se em direção à margem posterior dos segmentos. gineos.

Pernas pouco mais escuras que a cor geral do corpo; tarsos negro-ferru-

Macho: comprimento da cabeça 2,12; largura da cabeça 2,88; comprimento diante dos olhos 1,52; distância interocular 1,52 ; comprimento dos artículos antenais I, 1,06; II, 4,4; III, 3,04; IV, falta; comprimento do pronoto 3,04 ; largura do pronoto 7,14; comprimento do escutelo 6,08; largura do escutelo 4,4; largura abdominal 8,2; comprimento total 13,83 .

Genitália do macho: Tubérculos da parede dorsal do X segmento e do bordo dorsal do pigóforo menos pronunciados do que em $D$. lineatus e $D$. prolineatus. Projeções dorso-laterais do pigóforo de contorno quase retangular quando em vista lateral, ápice truncado. Parâmero semelhante ao de $D$. lineatus, porém com forma de losango menos nítida pela maior expansão da metade do losango voltada para a superfície ventral do pigóforo; aba expandida da região apical do parâmero mais ampla e mais pontiaguda; ápice do parâmero truncado (figs. 16 e 29). Phallus: curso da vésica quase retilíneo, porém inclinado para a superfície dorsal (figs. 50, 51 e 67).

Fêmea: comprimento da cabeça 2,53 (2,43 - 2,37); largura da cabeça $3,19(3,04$ - 3,34); comprimento diante dòs olhos 1,67; distância interocular $1,74(1,67-1,82)$; comprimento dos artículos antenais I, 1,36; II, 4,71 (4,56 $4,86)$; III, $3,22(3,04-3,34)$; IV, $2,93(2,88-3,04)$; comprimento do pronoto $3,26(3,04-3,49)$; largura do pronoto $8,23(8,05-8,51)$; comprimento do escutelo 6,49 (6,23 - 6,99); largura do escutelo 5,19 (5,01 - 5,32).

Genitália da fêmea: Placas genitais conforme ilustrado na figura 83 . Receptaculum seminis: capsula seminalis globosa, pars intermedialis duas vezes mais longa do que ela; porções do ductus anterior e posterior à área vesicular curtas em relação às demais espécies do gênero. Chitinellipsen presentes (fig. 90).

Diagnose diferencial: $D$. nigrodecoratus distingue-se facilmente das demais espécies do subgênero pela forma da cabeça e pela coloração peculiar da superfície dorsal.

Material examinado: BRASIL: Pará: holótipo fêmea - Taperinha, Santarém, 29/XII/1967 a 9/I/1968, Exp. Perm. Amaz., MZSP.

Parátipos: BRASIL: Pará: macho - mesmos dados do holótipo; fêmea Taperinha, sem data, G. Hagmann, MN. Mato Grosso: fêmea - Parque Nacional do Xingu, XI/1960, Alvarenga, Werner, DZPR; fêmea - Rio Verde, XI/1959, DZRS. Distrito Federal: fêmea - Santa Maria, Brasília, 2/XI/1970, N. Tangerino, MN.

\section{AGRADECIMENTOS}

Agradecemos aos curadores e responsáveis pelas coleções entomológicas que nos emprestaram tipos, cederam-nos material de comparação e prestaramnos informações: P. Wygodzinsky $(\mathrm{AMNH})$, W. R. Dolling $(\mathrm{BM}(\mathrm{NH}))$, J. S. Moure (DZPR), M. H. Galileo $(\mathrm{MCN})$, W. Overal (MG), R. Froeschner (NMNH), N. Moller-Andersen (ZM), P. Arnaud (CAS), J. A. Powell (CIS), J. H. Santos (FACE), N. Penny (INPA), J. Jurberg (IOC), E. Osuna (IZA, LS), F. Meyer (MA), J. Carayon (MP), V. Gapud (SEM), L. Schiavinato (ZUEC), M. Baehr e G. Scherer (Zoologische Staatssammlung München). Agradecemos também a Adriana Mohr o auxílio prestado na medição dos exemplares; a Ruth Hildebrad pela tradução da língua alemã e, em especial, a Fernando Dias de Ávila Pires pela leitura crítica do manuscrito. 


\section{REFERENCIAS}

Agassiz, L., 1842-1847. Nomenclator Zoologicus, nomina systematica generum animalium tam viventium quam fossilium, secundum ordinem alphabeticum disposita, adjectis autoribus, libris in quibus reperintur, anno editionis, etymologia et familiis ad quas pertinent in variis classibus. 393 pp. Soloduri.

Amyot, C. J. B. \& J. G. Audinet-Serville, 1843. Histoire Naturelle des Insectes. Hémiptères. 1xxvi + 681 pp., 12 est., Librairie Encyclopédique de Roret, Paris.

Becker, M. \& Grazia-Vieira, J., 1971. Contribuição ao conhecimento da superfamília Pentatomoidea na Venezuela (Heteroptera). Iheringia, ser. Zool. (40): $3-26$.

Bergroth, E., 1891. Contributions a l'étude des pentatomides. Revue Ent. 10: 200-235.

Bergroth, E., 1892. Notes synonymiques. Revue Ent. 11: 262-264.

Bosq, J. M., 1937. Lista preliminar de los Hemipteros (Heteropteros) especialmente relacionados com la agricultura nacional. Revta Soc. ent. argent. 9: 111-134.

Bosq, J. M., 1940. Idem (continuación). Ibid. 10: 399-417.

Burmeister, H., 1835. Handbuch der Entomologie. 2, Abt. I, ii $+400+$ 4 pp., 2 est. (Schnabelkerfe, Rhyngota). Berlin.

Costa Lima, A. M. da, 1927. Segundo catalogo systematico dos insectos que vivem nas plantas do Brasil e ensaio da bibliographia entomologica brasileira. Archos Esc. Sup. Agric. Med. Vet. 8(1-2): 78-81 (Hemiptera).

Costa Lima, A. M. da, 1936. Terceiro catalogo dos insectos que vivem nas plantas do Brasil. $460+$ iv pp. Rio de Janeiro, Escola Nacional de Agronomia.

Costa Lima, A. M. da, 1940. Insetos do Brasil. 2, Hemípteros 351 pp., Rio de Janeiro, Escola Nacional de Agronomia. (Série Didática n. 3).

Dallas, W. S., 1851. List of the specimens of Hemipterous insects in the collection of the British Museum. 1, 390 pp., 11 est., British Museum ed. London.

Dallas, W. S., 1852. Descriptions of some new species of hemipterous insects belonging to the tribe Scutata. Trans. $R$. ent. Soc. London 2(2): 6-19, f. 1-7.

De Geer, C., 1773. Mémoires pour servir à l'histoire des insectes. 3, 696 pp., 44 est., Stockholm.

Distant, W. L., 1880-1893. Rhynchota. 1, xx + 462 pp., 39 est. In Biologia Centrali-Americana, Insecta. Godman \& Salvin, London.

Dupuis, C., 1970. Heteroptera. pp. 190-208. f. 233-243. In S. L. Tuxen (Ed.) Taxonomist's Glossary of Genitalia of Insects. Munksgaard-Copenhaguen.

Erichson, W. F., 1848. Insecten. 3, pp. 553-617. In R. Schomburgk Reisen in British Guiana in den Jahren 1840-1844. J. J. Weber, Leipzig.

Fabricius, I. C., 1803. Systema Rhyngotorum secundum ordines, genera, species adjectis synonymis, locis, observationibus, descriptionibus. 335 pp. Brunsvigae.

Fallou, G., 1889. Description d'hémiptères nouveaux. Le Naturaliste 11(2): 120.

Gmelin, J. F., 1788. Caroli a Linné Systema Naturae; Ed. 13 aucta reformata. 1, part 4, pp. 2021-2224. Lipsiae.

Goeze, J. A. E., 1788. Entomologische Beitrage zu des Ritter Linné zwölften Ausgabe des Natursystems. 2, pp. 177-285 (Cimex) Leipzig.

Grazia, J. (no prelo). On some types of Pentatomidae deposited in the "Museum National d'Histoire Naturelle", Paris (Heteroptera). Bull. Mus. nat. Hist. nat. Paris.

Hahn, C. W., 1834. Die Wanzenartigen Insecten. 2, 142 pp. est. 37-72. Nürnberg.

Herrich-Schäffer, G. W. A., 1836. Ibidem. 3 pp. 26-109, f. 250-251; 278-283; 319-334. Nürnberg.

Herrich-Schäffer, G. W. A., 1844. Ibidem. 7, pp. 24-129, est. 225-252, f. 708787. Nürnberg. 
Kirkaldy, G. W., 1909. Catalogue of the Hemiptera (Heteroptera). 1. Cimicidae, 392 pp. Felix L. Dames, Berlin.

Laporte, F. L. de, 1832. Essai d'une classification systematique de l'ordre des Hémiptères. Mag. Zool. 1: 1-88, 5 est.

Latreille, M., 1829. Le règne animal II. Les crustacés, les arachnides et les insectes, distribués en familles naturelles. 4, xxvii + 584 pp.; 5, xxiv + 556 pp. Déterville, Paris.

Lethierry, L. \& G. Severin, 1893. Catalogue géneral des Hémiptères. Pentatomidae, $1, x+286$ pp. Bruxelles.

Linnaeus, C., 1758. Systema Naturae. 10. ${ }^{a}$ Ed., iv +824 pp. Stockholm.

Linnaeus, C., 1764. Museum S. R. M. Ludovicae Ulricae Reginae Svecorum, Gothorum, Vandalorum - 1, viii +720 pp. Stockholm.

Linnaeus, C., 1767. Systema Naturae. 12.a Ed. reformata. 1, pp. 715-733 (Cimex), Holmiae.

McAtee, W. L. \& J. R. Malloch, 1923. Further notes on names of Emesinae and other Rhynchota. Proc. biol. Soc. Wash. 36: 161-164.

Monte, O., 1937. Notas hemipterológicas. O Campo maio: 71.

Monte, O., 1939. Hemípteros fitófagos IV. Ibid. jan. 10(109): 51-53, 63.

Papavero, N., 1971. Essays on the history of Neotropical Dipterology, with special reference to collectors (1750-1905). 1, 216 pp. Museu de Zoologia, Universidade de São Paulo, São Paulo.

Pennington, M. S. 1920. Lista de los hemípteros heteropteros de la Republica Argentina. 1. 16 pp., Buenos Aires.

Perty, M., 1830-1834. Delectus animalium articulatorum, quae in itinere per Brasiliam annis 1817-1820 jussu et auspiciis Maximiliani Josephi Bavarie regis augustissimi peracto collegerunt Dr. J. B. de Spix et Dr. C. F. Ph. de Martius. 4 + 44222 pp., 40 est. Monachii.

Pirán, A. A., 1948. Contribucion al conocimiento de la dispersion geografica de los hemipteros neotropicales. Acta zool. lilloana 5: 5-17.

Pirán, A. A., 1956. Hemípteros raros o poco conocidos y no mencionados para las faunas de Brasil, Uruguay, Argentina, Paraguay y Bolivia. Revta Soc. urug. Ent. 1(1): 29-35.

Pirán, A. A., 1962. Hemiptera neotropica V. Notas sobre sistemática y zoogeografia de Pentatomidae. Acta zool. lilloana 18: 5-10.

Ruckes, H., 1958a. Four new species of Neotropical pentatomids (Heteroptera, Pentatomidae). Jl N. Y. ent. Soc. 66: 145-162.

Ruckes, H., 1958b. Some new genera ad species of Netropical pentatomids (Heteroptera). Am. Mus. Novit. (1918): 1-15.

Spinola, M., 1837. Essai sur les genres d'insectes appartenants à l'ordre des Hémiptères Lin. ou Rhyngotes Fab. et à la section des Hétéroptères Dufour. 383 pp. Genova.

Stal, C., 1866. Analecta hemipterologica. Berl. ent. Ztg 10: 151-172.

Stal, C., 1867. Bidrag till hemipterernas systematik. Ofvers. K. VetenskAkad. Förh. 24(7): 491-560.

Stal, C., 1868. Hemiptera Fabriciana. K. svenska VetenskAkad. Handl. 7(11): $1-148$

Stal, C., 1872. Enumeratio hemipterorum II. Ibid. 10(4): 1-159.

Walker, F., 1867-1868. Catalogue of the specimens of Heteropterus Hemiptera in the collection of the British Museum. 1 (1867), 1-240 pp.; 2 (1867), 241-418 pp.; 3 1868), 419-599 pp. British Museum ed. London.

Wolff, J. F., 1811. Icones Cimicum descriptionibus illustrate. Fasc. V, $167-$ 414 pp. est. XVII e XX, f. 157-200. 